\title{
Mahremiyetten Rızaya Dijital Albümler "Instagram Örneği"”
}

\author{
Digital Albums From Privacy to Consent \\ "Instagram Example"
}

Aslı Aydemir, Dr. Öğr. Üyesi, Dicle Üniversitesi İletişim Fakültesi, E-posta: asliaydemir6@hotmail.com

https://doi.org/10.47998/ikad.912140

\author{
Anahtar Kelimeler: \\ Mahremiyet, \\ Mahremiyetin İhlali, \\ Fotoğraf, \\ Sosyal Medya, \\ Instagram.
}

\section{Keywords:}

Privacy,

Violation of Privacy,

Photography,

Social Media, Instagram.

\section{$\ddot{O} z$}

Fotoğrafın icat edilmesi, sonrasında Osmanlılarda ilk uygulamalarının görülmesinden bugüne kadar fotoğraflar, geçmiși geleceğe aktaran kültürel bir miras olarak görülmektedir. Özellikle de 1960 'lı yıllardan itibaren Türk toplumunda aile toplantılarının olmazsa olmaz anlarından biri, fotoğraf albümlerine bakmak ve eski zamanlara dalıp yeni nesillere geçmişi aktarmaktır. En mahrem alanlar olan evlerde bakılan bu fotoğraf albümleri bir nevi ailenin gelecekteki nesillerine bir mirasıdır. Ancak günümüzde dijitalleşme ile birlikte en mahrem anların fotoğraflarının yer aldığı albümlerinin neredeyse yok denecek kadar azaldığı mahremiyetin de kişinin kendi rızasıyla başkaları tarafından beğenilme arzusuyla sosyal medya ortamlarında hiç çekinilmeden paylaşıldığı görülmektedir. Bu çalışmanın amacı da sosyal medya ortamlarında paylaşılan özel anlara ilişkin fotoğrafların kişisel rızayla mahremiyet algısındaki dönüşümünü örnekler üzerinden yorumlayabilmektir. Çalışma, nitel araştırma yöntemi olan doküman analizi yöntemiyle literatür kapsamında anlatılanları açıklayabilme kapasitesi bakımdan en yüksek verileri içeren bir fotoğraf paylaşım sitesi olan Instagram üzerinden rastgele yöntemle seçilen fotoğrafların analizini içermektedir. Analiz sonucunda, bireylerin aile, çocuk, doğum anı, evlilik kurumu, çalıştıkları kurumun mahremiyeti gibi her türlü mahrem alanlarını ve toplumsal bir statü kazanabilmek adına maddi varlıklarını kendi rızalarıyla ifşa ettikleri görülmüştür. Ayrıca "canım kendim" hashtagi ile paylaşım yapan kullanıcıların gözetlenme isteği ve beğenilme arzusuyla paylaşım yaptığı bir ortamda, narsist kişiliklerin arttığı ve modernleșme adı altında sosyal medya ortamlarında yaratılan kurguyla cehalet çıkmazına sürüklenen bir toplumun oluştuğu sonucuna varılmıştır.

\section{Abstract}

Since the invention of photography and its first applications in the Ottomans, photographs are seen as a cultural heritage that transmits the past to the future. Especially since the $1960 \mathrm{~s}$, one of the indispensable moments of family gatherings in Turkish society is to look at photo albums and to dive into the old times and transfer the past to the new generations. These photo albums, which are kept in homes, which are the most intimate areas, are a legacy of the family to future generations. However, nowadays, with the digitalization, it is seen that the albums containing the photographs of the most intimate moments are almost non-existent and the privacy is shared without any hesitation in social media environments with the desire to be liked by others with the consent of the person. The aim of this study is to interpret the transformation of the perception of privacy with personal consent, through examples, of photos of special moments shared on social media. The study includes the analysis of randomly selected photographs on Instagram, a photo sharing site that contains the highest data in terms of the capacity to explain what is described in the literature with the document analysis method, which is a qualitative research method. As a result of the analysis, it was seen that individuals disclose all kinds of intimate areas such as family, child, date of birth, marriage institution, privacy of the institution they work in, and their material assets in order to gain a social status. In addition, it has been observed that in an environment where users who post with the hashtag "dear myself" share with the desire to be watched and liked, narcissist personalities increased and a society was formed in a society that was dragged into a dilemma of ignorance with the fiction created in social media environments under the name of modernization. 


\section{Giriș}

Tarih boyunca çok çeşitli amaçlarla kullanılan fotoğraflar ilk olarak devletlerin bürokratik işlerinde delil amacıyla kullanılmış, daha sonra kültürel mirasın gelecekteki nesillere aktarılmasını sağlayan bir yöntem olmuştur. Günümüz dijital dünyasında ise fotoğraf kavramı çok basite indirgenerek kişilerin başkaları tarafından beğenilme isteğiyle sosyal medya ortamlarında anlık paylaşımların yapıldığ 1 bir araç haline gelmiştir.

20. yüzyılda kişilerin anılarını biriktirmek adına, özenle hazırlanılmış, tüm aile bireylerinin bir araya gelerek sıralandığı ve tek olma özelliğine sahip olan geçmişin masumiyeti ve mahremiyetini taşıyan fotoğraflar yerini, özensiz her saniyenin onlarca fotoğrafının olduğu akıllı telefonların içerisine hapsolan fotoğraflara bırakmıştır. Fotoğraf albümlerinin sayfalarını çevirirken her bir fotoğraf için yapılan yorumlar çok özel anların maneviyatını hissettirirken dijital ortamlarda yer alan fotoğrafların yerine saniyeler içerisinde yüzlercesi eklendiği için o kareler maneviyattan yoksun bir anı olarak kalmaktadır. Evlerin en özel ve mahrem alanlarında saklanan ve sadece insanların hayatlarında özel bir yeri olan kişilerle paylaşılan bu fotoğraflar mahremiyet algısında yaşanan dönüşümle hiç tanınmayan milyonlarca insanın beğenisine sunulmaktadır.

20. yüzyılın sonlarıyla gelişen internet kavramı özellikle 21. yüzyıl ile birlikte akıllı telefonların kullanımın yaygınlaşması ve internete ulaşım imkânlarının artmasıyla herkesin iyi-kötü fark etmeksizin her anını fotoğrafladığı ve anında sosyal medya ortamlarında paylaşıma sunduğu görülmektedir. İnsanlar hiç çekinmeden doğum anlarını, düğünlerini, sünnetlerini, taziyelerini, aile yemeklerini, çocuklarını, gittikleri mekânları, dini tercihlerine ilişkin durumlarını, dinledikleri müzik türleri vb. birçok mahrem anlarını sosyal medya ortamlarında paylaşarak bireysel mahremiyetlerinin yanı sıra o fotoğraf karesinde yer alan kişiler bağlamında ailesel mahremiyeti de ihlal etmektedir. Ayrıca çoğu zaman dışarıdaki mekânlarda çekilen fotoğraflarda kadraja giren durumdan habersiz yabancı kişilerin mahremiyeti de ihlal edilmektedir.

Dijitalleşmenin ve sosyal medya ortamlarının bilinçsiz bir şekilde kullanılmasının olumsuz yönlerinden biri de söz konusu ortamlara yüklenen fotoğrafların siz paylaşımı kaldırsanız dahi dijital ortamlarda varlığını sürdürmekte olduğudur. $\mathrm{Bu}$ durumdan habersiz birçok kullanıcı daha sonra yapmış olduğu paylaşımın aleyhine kullanıldığı durumlarla karşılaşmaktadır. Sosyal medyanın yaşamın ayrılmaz bir parçası haline geldiği ve insanların zaman geçirmekten zevk aldığ 1 bir ortam olmasıyla yapılan her türlü paylaşım, Huxley'in Cesur Yeni Dünya'nda olduğu gibi “insanlar keyfe ve hazza yönelme dürtüleri sayesinde kontrol ediliyorlardı" sözünü doğrulamakla kalmayıp belki de Huxley’in endişelendiği gibi sevilen şeyler insanı yıkıma götürecektir.

\section{Mahremiyet Olgusu ve Boyutları}

Mahrem, hürmet kelimesinden türemiş olup sözlükte "helal olmayan, yasaklanan şey" anlamındadır. Gizlilik, aile hayatı olarak da kullanılan mahrem kelimesi Kur'ân-1 Kerim'de "vücutta gizli kalması, örtülmesi gereken yerler" ve "gizlilik" manalarında kullanılmış olup hadislerde de birçok kere kullanıldığı görülmektedir (Aktaran: Çekiç, 
2020: 10). Arapça kökenli bir kelime olan mahremiyet kavramının manası gizlilik (Türk Dil Kurumu, 2021) olup kişinin yaşam tarzını belirleyen bir olgudur.

Mahremiyet, insanın yaradılışında doğduğu andan yaşamının tüm evlerinde izlerinin görülmesi gereken özel hayatın gizli olması kavramıdır. Mahremiyet denince akla ilk olarak gelen bedenin mahremiyetinin yanı sıra maddi varlık, duygusal ilişkiler, iş hayatı, çocuk mahremiyeti de gizli olması gereken alanlardır. Ancak mahremiyet toplumdan topluma, kültür yapılarına, tabii olunan dine, kişiden kişiye ve hatta bazı durumlarda kişinin yaşadığı duruma göre de farklılık gösterebilen bir kavramdır.

Bireyin özel hayatıyla ilgili bir kavram olan mahremiyet kavramı İngilizce'de "privacy" kelimesiyle tanımlanmakta olup Solove tarafından düşünce özgürlüğünü, kişinin vücudunu kontrol etmesini, evdeki yalnızlığı, kişisel bilgiler üzerindeki kontrolü, gözetim özgürlüğünü, itibarını korumasını, aramalardan ve sorgulamalardan korunabilmesini kapsayan bir alan olarak ifade edilmektedir (Solove, 2008: 1). Bu bakış açısıyla mahremiyet insan olmanın gerektirdiği temel bir ihtiyaçtır. Nasıl ki kişinin başkalarıyla iletişim kurarak sosyalleşme, ihtiyacı varsa istediği zaman mahrem alanında tek başına kalma isteği de bir ihtiyaç olarak görülmelidir. Kendi rızasıyla başka insanlarla siyasi, dini düşüncesini, duygusal ilişkilerini, aylık kazancının ne kadar olduğu gibi konuları paylaşan kişiler olduğu gibi bunları mahrem olarak gördüğü için paylaşmak istemeyen kişiler de bulunmaktadır. Bu durumda da kişinin bu düşüncesine saygı duyulup mahremiyetini paylaşma konusunda ısrarcı olunmamalıdır.

Hayatın birçok döneminde mahremiyet olgusunun olduğu görülmekle birlikte Rosenberg ve Holvast mahremiyetin, bölgesel, bireysel, ve bilgi mahremiyeti olarak üç temel özellikte olduğunu vurgulamaktadır. Bölgesel mahremiyette, kişinin etrafindaki en yakın fiziksel alanı koruması söz konudur. Buradaki mekânsal algı, kişinin en yakın alanı olan evinden başlamakta ve kendisine yakın olan her türlü fiziki ortamın mahremiyetinin olmasının ve bunun korunmasının gerekliliği üzerinde durulmaktadır. Bireysel mahremiyette, kişinin mahrem alanı olarak akla ilk gelen bedenini yersiz müdahalelere karşı korunmasının gerekliliği üzerinde durulur. Son olarak bilgi mahremiyetinde ise, kişisel verilerin toplanıp toplanamayacağı, nasıl saklanacağı, işleneceği, nasıl dağıtılıp yayılabileceğinin kontrol edilmesi söz konusudur (Fischer, 1998: 422). Çalışmanın analizi, mahrem olanın kişisel rızayla sosyal medya ortamlarındaki paylaşımlar ile mahremiyette olması gereken üç temel özelliğin bilinçli olarak nasıl ihlal edildiğini açık bir şekilde göstermektedir. Kişiler, sosyal medya ortamlarında yapmış oldukları fotoğraf paylaşımlarıyla sadece kendi mahremlerini değil fotoğraf kadrajında yer alan kişilerin, belki gizli kalması gerekli olan bilginin, mekânın vb. her türlü mahrem olanın ihlalini gerçekleştirmiş olmaktadırlar.

Kişinin kendi özel alanını koruması gerektiği gibi başkalarının da özel alanlarını koruması gerekmektedir. Bu nedenle özel hayatı korumak kamunun alanını göz ardı etmek olarak algılanmamalıdır. Kişinin kendi özel alanına ihtiyacı olduğu gibi kamusal alana da ihtiyacı vardır. Bu ihtiyaç çerçevesinde özel alanın sınırları ile kamusal alanın sınırlarının kişi tarafından bilinmesi gerekmektedir. Mahremiyetin mühim bir yönü de vatandaşın toplumdaki itibarının korunması ve şahsi bilginin denetiminin olduğu bir mekanizmanın 
olmasıdır. Çünkü toplum içindeki itibar, kişinin bireysel ilişkilerini, ticari faaliyetlerini, kendini tanıtabilme imkânlarını etkileme gücüne sahip olmakla birlikte kişinin özgürlüğü büyük bir oranda resmi itibarına bağlıdır (Lokke, 2020: 20).

Mahremiyet ve özel hayata saygı yasalarca da güvence altına alınmıştır. Avrupa İnsan Hakları Sözleşmesi (AİHS)'nin 8. maddesi “özel ve aile hayatına saygı hakkı”nda yer aldığı gibi; "Herkes özel ve aile hayatına, konutuna ve yazışmasına saygl gösterilmesi hakkına sahiptir. Bu hakkın kullanılmasına bir kamu makamının müdahalesi, ancak müdahalenin yasayla öngörülmüş ve demokratik bir toplumda ulusal güvenlik, kamu güvenliği, ülkenin ekonomik refahl, düzenin korunmasl, suç işlenmesinin önlenmesi, sağliğın veya ahlakın veya başkalarının hak ve özgürlüklerinin korunması için gerekli bir tedbir olması durumunda söz konusu olabilir." (Anayasa Mahkemesi, 2021). Ayn1 zamanda Avrupa Konseyi Parlamenterler Meclisi tarafindan kabul edilen 1970 tarih ve 428 sayılı Kitle İletişim Basını ve İnsan Hakları Hakkında Bildiri'de “Özel hayatın gizliliği hakkı aslında kişinin en az müdahale ile hayatını sürdürmesi hakkını içerir. Özel, aile ve ev hayatı, fizikî ve moral bütünlük, onur ve saygınlık, kişinin yanlış tanıtılmasından kaçınılması, ilgisiz ve utandırıcı gerçeklerin açıklanmaması, özel fotoğrafların izinsiz yayımlanmaması, özel iletişimin kötüye kullanılmalara karsı korunması, sır olarak verilen veya alınan bilgilerin açıklanmasının engellenmesi bu kapsam içerisinde yer alır." ifadeleri ile tanımlanmıştır (Duman, 2012: 303). Anayasal haklarla da güvence altına alınan ve başka insanların kişinin mahremiyetine müdahalesinin söz konusu olmadığ 1 , bu tarz girişimlerde bulunanların yasalar tarafından suçlu sayılacağı söz konusuyken kişinin kendi rızasıyla kendi mahremini ihlal etmesi büyük bir sorunsaldır.

\section{Geçmişten Günümüze Mahremiyetin Dönüşümü}

İnsanlığın ilk döneminden beri var olan toplumsallaşmayla birlikte kendini daha çok hissettiren mahremiyet olgusu zaman içerisinde birçok yönden değişime uğramıştır. Toplumsallaşma sonrası kentleşme ve sanayileşmeyle birlikte bireyin geleneksel yap1 içerisindeki konumu farklılaşarak modern toplumun gereklerini yerine getiren bireye dönüşmesine neden olmuştur.

Değișen birey ile birlikte mahremiyet algısı da modernleşme sonrası bugünkü anlamıyla kullanılmaya başlanmıştır. Kültürlerin geçmişini inceleyen çalışmalarda en ilkel toplumlardan modern toplumlara geçişte hem birey hem de aile kurumu açısından mahremiyete yönelik fiziksel ve psikolojik firsatların giderek arttı̆̆ı görülmektedir. Geleneksel toplumlarda hem birey kendisini bağlı bulunduğu toplumsal gruba göre tanımlar ve konumlandırır hem de bireyi tanımlayan diğer kişiler. Bu durumdaki birey ya birinin kocası, kardeşi, oğlu, kızı, annesidir ya da A köyünden veya B kabilesindendir. Bu durumda olan bir insanın yaşamı modernleşme koşullarında varlığını yitirir. Geleneksel toplum hayatında mahremiyet olgusu günümüzdekiyle kıyaslanamayacak bir boyuta sahip olmakla birlikte ulaşılmak için çaba sarf edilen bir olgu olmadığ gibi varlığ bile bilinmeyen bir şeydi. Modern öncesi toplumlarda insanın özgürlüğü, hayatın her döneminde her alanında akraba, komşu, ölüm veya yaşamın kendisinin baskısıyla sınırlıdır. Birey bu baskılardan kaçamayacağı için de mahremiyet alanı çok dardır (Aktaran: Yüksel, 
2003: 189). Bu bağlamda toplum içindeki bireyin kişisel hakları ve özgürlüğü yakını, eşi, dostu, komşusu veya mensubu olduğu topluluk tarafından kısıtlanıyorsa bireyin tam bir mahrem alanı olduğunu söylemek mümkün değildir.

Özel hayat ve kamu arasındaki bölünmenin şehir hayatının var olmasıyla birlikte ortaya çıktığı söylenebilir. Eski Yunanlılar şehrin ve siyasetin alanı olan polis ile, aile ve ev alanı olan oikos arasına bir sınır çizerek ev hayatı ve şehir hayatını birbirinden ayırmışlardır. Eski Roma'da da res publica ile res privata farklı iktidar ve varlık alanlarını açıklamaktaydı. Ancak eski devletlerdeki bu bölünmeler bugünkü modern anlamdaki bölünmelerin başlangıcı sayılmamaktadır. Çünkü modern insan, kamusal alanı zorunlulukların ve görevlerin alanı olarak, özel alanı ise daha özgür ve daha doğal bir alan olarak görmeye daha yatkındır. Oysaki Eski Yunan'da aile ve ev alanı olan oikos kişinin kendini yeniden üretmesini sağlayan ev hayatının, çalışmanın, ekonominin alanıydı. Bu anlamda modern insanın ev hayatını doğal bir ortam olarak görmesinin aksine özgürlük alanından çok bir zorunluluk alanına giriliyordu. Özgür alana doğru gitmek için ise oikosun dışına polis alanına girmek gerekmekteydi ki polis özgür erkeklerin oikos ise, bu özgürlükten mahrum bırakılan zorunluluk alanına hapsedilmiş kadın, çocuk ve kölelerin bölgesiydi (Gürbilek, 2001: 56). Bu bağlamda eski şehir devletlerindeki özel alan-kamusal alan ayrımının modern insanın yapmış olduğu ayrımdan farklı olduğu görülmektedir. Günümüzde kişinin özel alanı olan ev mahremiyeti en özgür olması gereken alanken Eski Yunan'da insanın ekonomik faaliyetleri yürütebilmesi için gerekli olan çalışma alanı olarak görülmekteydi. Yani modern insanın iş alanı olan kamusal alan Eski Yunan'da özel hayatın içerisinde olarak mahrem alanın ihlal edilmesiyle tezahür etmekteydi.

Türkiye'de de sanayi toplumu öncesi ilkel ve tarım toplumlarının var olduğu bir yaşam biçimi varken Osmanlı Dönemi'nin sonlarından itibaren kentleşme ve sanayileşme ile birlikte yaşam biçimlerinde de değişikler yaşanmıştır ki mahremiyet alanındaki asıl dönüşüm de bu dönemde başlamıştır. Yaşam biçimindeki değişikliklerin yanı sıra bir ülkede yaşayan bütün insanları etkileme gücüne sahip olan ekonomik ve siyasi olaylar ile iletişim sistemindeki değişimler birçok alanı etkilediği gibi mahremiyet algısının da değişmesine neden olmuştur (Çevik, 2019: 27). Türkiye'de mahremiyet alanındaki önemli gelişmelerin yaşandığ dönemlerden biri de 1980'li yıllardır. O döneme kadar "mahrem" olarak cinsellik, cinsel eğilimler, kuşaklar vb. birçok konu 80'lerde kamuoyu gündemine gelerek kamusal bir söz düzeni içerisinde konuşularak ayrıştırılmıştır. Batı toplumlarının tarihiyle bağlantı kurularak özel hayatın söyleme dönüştürülerek gündeme gelmesi, Türkiye'nin Batılılaşmasının kanıtı olduğu söylenebilir. Özel hayat olarak ayrı bir yapının olduğundan söz edebilmek için öncelikle bir adlandırılma yapılması -kamusal alanda adlandırılma- ve onunla ilgili bir kamuoyu oluşması gerekmektedir ki 80'li yıllar bu kavramı literatüre kazandırmıştır (Gürbilek, 2001: 22). 80’li yılardan sonra önemli bir toplumsal değişim süreci ise küreselleşmeye bağlı olarak toplumsal yapı içerisinde meydana gelen değişiklikler ve dönüşümlerdir.

Toplumsal yapının dönüşümde önemli bir etken iletişim teknolojilerindeki değişimler zamanın ve mekânın sınırsızlaşmasını ve dünyanın McLuhan'ın söylemiş olduğu gibi küresel bir köye dönüşmesine olanak tanışmıştır. Bu küresel köy, insanların mahrem alanını nasıl belirlediği noktasında da bir değişikliğe neden olmuştur. Kamusal 
alanlarda paylaşılan mahrem anlar, aile, akrabalık ilişkileri gibi özel olan birçok alanın da özel olmaktan çıktığını göstermektedir.

Giddens, mahremiyetin dönüşümünün toplum yaşamının farklı alanlarında ortaya çıkabildiğini söylemektedir. Mahremiyetin baskıcı bir durum olduğunu söyleyenler de vardır, eşit şartlara sahip iki insanın aralarındaki ilişkiyi karşılıklı olarak görüşebildiği bir durum olduğunu söyleyenler de. Mahremiyet, kamusal alandaki demokrasi ile uyumlu olarak, kişiler arası ortamın kökten demokratikleşmesini içeren bir kavram olarak da tanımlanmaktadır. Giddens aynı zamanda mahremiyetin dönüşümünün modern kurumlar üzerinde dönüştürücü tesiri olabileceğini söyler. Çünkü ona göre en büyük ekonomik gelişme amacı yerine duygusal anlamda oluşan tatminin olduğu bir dünya bugünkünden farklı olacaktır. Şu anda cinselliği etkileyen değişimler şiddetle yenilikçidirler. Mahremiyetin dönüşümü bilhassa seks ve cinsiyet alanlarında olmakla birlikte o alanlarla kısıtlanmamıştır; tamamıyla kişinin kendi yaşamındaki ahlaki değerlerinde esas bir değişim olduğu vurgulanmaktadır (Giddens, 1992: 9-91). Bu bağlamda cinsiyetçi bir yaklaşım tarzıyla İslami kimliğe sahip olan kadınların da kamusal alanda söz sahibi olmaları için verdikleri mücadele kadar mahrem alanda yaşamış oldukları aşk tecrübeleriyle "mahrem" olanı dönüştürmeleri de önemlidir (Türkmen, 2012: 130). Toplumların değişimi ve mahremiyetin dönüşümü çerçevesinde özellikle 90'l1 yılların sonu 2000'li yılların başında yaşanan bu gelişme Giddens'ın mahremiyetin dönüşümü olarak üzerinde durduğu "seks ve cinsiyet" alanıyla paralellik göstermektedir.

Baudrillard ise bir tüketim nesnesi olarak gördüğü "beden"in kamuyla paylaşılmasını şu şekilde ifade etmektedir; bin yıllık püritenlik dönemi sonrası cinsel ve fiziksel olarak özgürleşme şekli ile bedenin "yeniden keşfi", moda, reklam ve kitle kültüründeki varlığı -bedenin etrafını çevreleyen sağlık, tedavi, diyet, gençlik, zariflik, erkeklik/kadınlık saplantısı, bedenle alakalı olan bakım, rejim, özverili durumlar ve arzu söylemi- gibi haller günümüzde bedenin kurtuluş nesnesine dönüştüğünü gösterir ki bu ahlaki ve ideolojik fonksiyonda beden ruhun yerini almış durumdadır (Baudrillard, 2017: 163). Bedenin ruhun yerini alması ve teşhiri günümüzde çok fazla karşımıza çıkan bir durum olmakla birlikte Etzioni mahremiyet ihlalini şu şekilde açıklamaktadır; önceki dönemlerde özel hayat ve mahremiyet alanının ihlali denince tehdit olarak daha çok kamu politikaları ve devlet akla gelince günümüzde ise mahremiyetin ihlal edilmesi noktasında özel kişi ve kuruluşlardan kaynaklı tehditler de risk olabilmektedir (Yüksel, 2003: 207). Etzioni'nin belirttiği gibi günümüz modern ve küresel toplumlarında kişiler devlet ve kamu politikalarının özel yaşam alanlarının mahremiyetini ihlal ettiklerini söylerken bir yandan da aslında kendi rızalarıyla en mahrem alanlarını kamuyla paylaşarak kendi özel alanlarını kendileri deşifre etmektedirler.

Modernleşme süreci ve kişilerin adına dürüstlük ve şeffaflık diyerek mahrem olan özel hayatlarını ortaya dökmeleri sonucu kişiye ait olan özel alanda dönüşüm yaşanmıştır. Bu dönüşümün yaşanmasında bazı gelişmeler etkili olmuştur. Modernleşme ile birlikte mahremiyetin dönüşümde etkili olan önemli bir etken, bilgi ve iletişim teknolojilerindeki gelişmeler ile medya organları, internet ortamları, telefonlar, gözetimi sağlayan araçların ortaya çıkmasıdır. Sosyo-kültürel anlamda yaşanan gelişmeler, sanayi devriminin ardından aile ve iş yaşamında bir takım değişikler oluşması sonrası, eğitim seviyesinin 
yükselmesi ile insanların fikirlerini rahatça dile getirebildikleri daha özgür bir ortamın oluşturulma çabası da mahremiyet algısının dönüşümünde etkili olan bir diğer önemli etkendir. Ekonomi alanında yaşanan değişimler neticesinde insanların alım güçlerinin ve ürünlerin pazarlama stratejilerinin artması ile kişiler teknolojik gelişmeleri çok yakından takip etmeye başlamışlardır. Bu durum da yaşanan bu dönüşüm sürecinde etkili olmuştur. Siyasal alandaki değişimlerde de kamu yararı olduğu düşüncesiyle bazı gözetleme yöntemleri kullanılmış ki bu da mahremiyetin ihlali durumunu ortaya çıkaran bir diğer etken olmuştur (Çelikoğlu, 2008: 24). Toplumsal hayat algılayışı, yaşam tarzındaki değişmeler ve yaşanan dönüşüm ile birlikte eski zamanlarda mahrem sayılanın şimdilerde mahrem olmaktan çıtı̆̆ 1 görülmekle birlikte neredeyse mahrem alanı gizleyenlerin, bu alanın özel olduğunu ve bu nedenle başka insanların beğenilmesine sunulmasının yanlış olduğunu düşünen insanların olumsuz anlamda eleştirildiği bir ortamın var olduğunu söylemek yerinde olacaktır. Hatta mahrem olanın ifşa edilmemesi gerektiğini söyleyenler aksini düşünen insanlar tarafindan, modern olmayan, bağnaz insan olarak bile nitelendirilebilmektedir.

\section{Mahremiyetin Rızayla Teşhiri: Sosyal Medyada Mahremiyet Algısı}

Küreselleşmeye bağlı olarak iletişim teknolojilerinin değişimi kişilerin yaşam tarzlarının da değişmesine ve mahrem algısındaki farklılaşmaya neden olmuştur. Daha önceleri kişinin mahremi olan her türlü bilgi, belge, fotoğraf kişinin kendisi tarafindan korunurken yaşanan teknolojik değişimler neticesinde bu bilgiler, kişinin kendisi tarafından teşhir edilmesiyle tezahür etmiştir.

Eski zamanlarda insanlar aileleriyle birlikte vakit geçirirken, mahrem alanları olan evlerinde sadece kendileri için özel olan insanlarla özel paylaşımlarda bulunup fotoğraf albümlerinin sayfalarını özel muhabbetlerle çevirirken şimdilerde o özel anları sosyal medya ortamlarında oluşturmaktadırlar. Hatta yeni tip yaşam tarzında sadece paylaşım alanları değişmekle kalmamış aile kavramı bile farklı bir algıya bürünmüştür. İnsanlar sosyal medya ortamlarındaki takipçileri ve takip ettikleri kişileri "aile" olarak nitelendirirken gerçek anlamdaki aile bireylerin sosyal medya ortamlarındaki hesaplarını takip etmemekte hatta bazen kendilerinden gelen takip isteklerini bile kabul etmemekte ya da engellenmektedirler.

Rıza ve mahremiyet eski dönemlerden beri birbiriyle ilintili kavramlar olarak karşımıza çıkmaktadır. Daha önceki yıllarda rıza bir taraftan "can damarı" olarak görülür bir taraftan da "gazetecilerin yalnızca kendi rızasını aldıkları kişiler hakkında yazmaları gerektiği sonucuna varmak hatalı olur" denirdi. Burada yapılması gereken önemli bir ayrım bulunmaktadır. Açık bir şekilde yaşayan insanların rızalarının alınması beklenebilir. Mahremiyetlerinin korunmasının sınırlı olduğu kamuya mal olmuş şahsiyetlerin küçük bir koruma alanı dışında yine rızaları alınabilir. Ancak bazı durumlarda rıza alınmasına gerek yoktur ki bunlar; yolsuzluğa, suça, iki yüzlülüğe, etik olmayan davranışlara karışma halleridir. Diğer tüm durumlarda ise kendilerini halkın gözleri önünde buluveren sıradan insanların ve olaylarla hiçbir ilgisi olmayan masum aile fertlerinin mutlaka rızaları alınmalıdır (Belsey ve Chadwick, 1998: 117). Gazetecilikte bir haber yaparken kişilerin 
rızasının alınmasının önemi ve mahrem alana müdahalenin olmamasının gerekliliğinden günümüz dünyasında başkasının yayın yapmasına rıza göstermeyeceğimiz birçok mahrem alanımızı kendi rızamızla özenerek süsleyerek bir meta haline dönüştürerek kamusal ortamlara altın tepside sunmaktayı.

Kişinin en mahrem alanı olan bedeni, ailesi, evi, kıyafetleri, sahip olduğu malları kişinin maddi benliğini oluşturmaktadır. İnsanların birbirleriyle ilişki içerisinde olması ve yaşanan etkileşim süreci sosyal benliğini, düşünme hissetme, algılama vb. ruhi etkinlikleri ise ruhsal benliğini oluşturmaktadır. Bu üç benlik biçimi kişinin sosyal yaşamında diğer insanlarla paylaşımları sonucunda oluşmakta ve kişinin benlik bilinci de bu üç benliğin bir arada olmasıyla ortaya çıkmaktadır. Bunun sonucu olarak da kişinin kendi iç dünyası ile barışık olma seviyesi benlik saygısını göstermektedir (Ertürk, 2010: 102). Kişi kendiyle ne kadar barışıksa kendine güveni ne kadar fazlaysa benlik saygısı da o kadar gelişmiştir. Benlik saygısı gelişmiş kişinin başka insanlarla kurduğu iletişim, sosyal ortamlarda var olma durumu da o oranda fazladır. Ancak günümüzde insanlar Habermas'ın kamusal alan olarak nitelendirdiği cafeler, meydanlar, sosyalleşme ortamlarında iletişim kurmak yerine sanal kamusal alanlar olan sosyal medya ortamlarında iletişim kurmayı tercih etmektedir (Aydemir, 2020: 124). Bu ortamlarda kişinin gerçek bir benlik saygısının oluştuğunu söylemek mümkün olmamaktadır. Çünkü insanlar gerçek bir iletişim ortamından uzak akıllı telefonların, tabletlerin, bilgisayarların soğuk ekranlarında iletişim kurmaktadırlar. Böyle bir durumda da kişinin maddi benliğini oluşturan bedeni, ailesi, evi, sahip olduğu maddi varlığı vb. en mahrem olan alanları sosyal medya ortamlarında yüzlerce kişinin beğenisi alma dürtüsüyle kendi rızasıyla teşhir edilmektedir. Böylelikle de geçmişi hatırlamak ve gelecek nesillere de aile bağlarını, kültürü bir miras olarak bırakma işlevi gören fotoğraf albümleri, dijital ortamlarda sadece beğenilme arzusuyla teşhir edilen bir metaya dönüşmüştür.

Sosyal medya ortamlarında geçirilen zamanın kişinin günlük hayatının büyük bir bölümünü alması ve yapılan paylaşımlarla mahrem alanın kamusal alanda yer alması Facebook'un kurucusu Mark Zuckerberg'in 'Facebook'ta yer almak istiyorsanı, mahremiyetinizden vazgeçeceksiniz" sözünü kanıtlar niteliktedir (Arık, 2018: 161). Dijitalleşen dünyada teknoloji kullanımının yaygınlaşmasıyla birlikte dijital gözetim insanın gündelik hayatının içine derinlemesine sızarak mahremiyeti yok etmiş, Foucault'un "gözetim toplumu” kavramını "gözetlenmek isteyen toplum” kavramına dönüştürmüştür.

İletişim teknolojilerindeki yeni gelişmeler ve gözetim araçları bir taraftan bireyin tam olarak farkındalığının olmadığ 1 ve rızası olmadan mahremiyetini bütün ayrıntısıyla bir meta gibi dolaşıma sokarken bir taraftan da sınırsız toplumsallaşma vaadiyle kişinin kendi rızasını oluşturmak suretiyle mahremiyetini kamusal hale getirmektedir. Endüstri sosyal medya araçları vasıtasıyla kişiye hâkimiyet alanı sunarak, varlığını sosyal medyada haykırmak isteyen bireyin gerçekte mahremini endüstrinin hükümranlığına teslim etmektedir. Bireyi bir obje haline getiren dijital teknolojiler, ister kişinin kendi rızasıyla isterse rızası dışında olsun, kişisel verilerden beslenerek bireyin mahremiyetini ihlal etmekte ve endüstriyi yeniden üretmektedir. Sosyal medya ortamları kişilere aracısız bir şekilde kendilerini ifade edebilme imkânı tanımakta, mahrem alanlarını ifşa ettikleri takdirde beğenilme ve hatta ünlü olma olanağı sunmaktadır. Sosyal medya 
ortamlarında takip edilmek mesajların beğenilmesi, paylaşılması bireye toplumsal bir statü kazandırmakla birlikte, gözetleme ve teşhir duygularını da harekete geçirmektedir. Bu durumda mahremiyetin sınırlarının açılması başka bir noktada paylaşımın hem maddi hem de manevi boyutuna katkı sunmaktadır. En kıymetli mahremiyet paylaşımı bedendir ki sosyal medya ortamları bedenin teşhir edilmesinde kışkırtıcı bir rol üstlenirken bir taraftan da mahremiyetin sınırlarını daraltmaktadır. Günümüzde beden tarihte benzerine rastlanmayacak şekilde metalaşmıştır (Arık, 2018: 175). Benlik bilinciyle ve beğenilme arzusuyla çekilen "selfie" olarak dünya literatüründe yerine alan kişinin kendini veya kendisiyle birlikte başkalarını da kadraja aldığı fotoğraflar da bedenin ifşa edilmesi noktasında önemli bir husustur.

Kişi yapmış olduğu selfie ile paylaşım yapmak istediği zaman çektiği çok sayıda fotoğraf arasından en güzel göründüğ̈̈nü seçmeye çabalar ve bunu bazı uygulamalar sayesinde düzenler. Bunu da "daha iyi görünürse daha çok beğenileceği” düşüncesiyle yaptığını söylemek yerinde olacaktır. Bireyin kendisi hakkında olumlu yönde konuşulması, beynin haz bölgelerinin harekete geçiren bir süreç olup bu durumdan bilhassa gençler daha da etkilenmektedirler. Selfie de bu anlamda kendilerine akranları tarafindan tanınma ve kendileri ile ilgili geri bildirim almalarına yardımcı olmaktadır (Özdemir, 2020: 51). Olumlu yönde geri bildirim alan kişi yaşadığı haz ile sosyal medya ortamında daha çok vakit geçirerek her geçen gün paylaşımlarını da artırmaktadır.

Sosyal medya ortamlarında geçirilen vakit ve yapılan paylaşımlar bakımından son yılların hareketli ve etkileşimi en yüksek sosyal ağı Instagram'dır. Instagram yazıyı değil görüntüyü öne çıkaran bir uygulama olması bakımdan kişilerin tam da aradığı özellikte bir ortamdır ve Facebook tarafından satın alındıktan sonra hızlı bir yükselişe geçmiştir. Günümüzde gözetleme ve gözetlenmenin en yoğun olduğu sosyal medya ortamı olan Instagram'ın kullanıcı profili Facebook'a göre daha elittir. Özellikle de kullanıcı profilinde ünlü insanların çok fazla olması -ya da sık görünenlerin ünlü olması- sıradan insanların o ortamda onları takip etmesi ve onlar gibi olmak isteyen kitlenin öncelikli olarak kullandığ 1 bir sosyal medya ortamı olmasına neden olmuştur. Instagram ortamında bu özelliklere sahip kitlelerin yanı sıra ünlü olmayan ama orada yapmış oldukları paylaşımlarla hatırı sayılır bir takipçi sayısına ulaşan kişilerin de mahremiyetlerini kamusallaştırma konusunda istekli oldukları görülmektedir. Gözetlemeye yatkın olan kitlenin bu gözetleme ihtiyacını karşılaması bakımından en uygun sosyal medya ortamı olan Instagram fenomenleri özel hayatlarını deşifre ederek belirli bir kitleyi ele geçirerek değerinin takipçi sayısıyla belirlendiği bir ortamda endüstriyel değerlerini yükseltmektedirler (Arık, 2018: 185). Benlik duygusunu sosyal medya ortamlarında yüceltmek isteyen ve bu isteklere cevap vererek gözetleyen insanların kendi rızalarıyla mahremiyetlerini kamusallaştırmaları değişen mahremiyet algısının sosyal medya ortamlarında nasıl dönüştüğünün açık bir kanitidir.

Sosyal medya ortamlarında teşhir edilen mahremiyet durum tersine döndüğü zaman dijital mahremiyetin korunamaması sorununu ortaya çıkarmaktadır. Çünkü yapılan paylaşımlardan rahatsızlık duyan ve o paylaşımları dijital ortamdan kaldırmak isteyen kişi o uygulamadan kaldırıyor olsa da dijital ortamlarda özellikle de arama motorlarında o bilgiler bir şekilde sonsuz olarak saklı durmaktadır. İşte tam da bu noktada 2012 yılı itibarıyla "unutulma hakkı" kavramıyla tanışılmıştır. 
Unutulma hakkı, kişilerin kendileriyle ya da kurumlanyla ilgili olarak dijital ortamlarda yer alan her türlü bilgi, belge, fotoğraf vb. dokümanların -arama motorlarında tarandığı zaman- sıralanmamasını ve her türlü bilginin kişinin kendi isteği üzerine dijital ortamlardan kaldırılmasını isteme hakkıdır. Bu hak, 13 Mayıs 2014'te AB. Mahkemesi'nde; "Veri sahibi, kişisel olarak kendisiyle ilgili söz konusu bilgilerin, artık adı temelinde yapılan bir aramanın ardından görüntülenen bir sonuç listesiyle kendi adına bağlanmaması hakkına sahiptir. Bu hak doğrultusunda böyle bir sonuç listesine dâhil edilmesi nedeniyle artık kamuoyuna açıklanmamasını arama motorlarından talep etme hakkına sahiptir." (Judgment Of The Court (Grand Chamber)) kararıyla gündemde yerini almıştır. Ancak alınan kararlar, "Kişisel verilerinin kaldırılması talebinde bulunan kişinin sadece yaşadığı coğrafi sınırlar içerisinde mi yayından kaldırılacak yoksa tüm dünya genelinde mi?" net olarak belirlenememiştir. Bu nedenledir ki teknolojik altyapı nedeniyle tam olarak bir unutulmanın söz konusu olamayacağı için bu hakkın tam bir koruma sağladığı da savunulmayacaktır. Ancak bu hakkın tam bir unutma sağlama amaçlamadığı sadece kişisel verilerin teknolojinin sağladığı kolaylıkla ulaşılabilme özelliği ile verilen zararı azaltabilmek olduğu düşünülürse şu anda var olan düzenlemelerin yeterli olduğu söylenebilir (Nalbantoğlu, 2018: 599). Yapılan düzenlemelerin bile kişisel verileri korumak adına tam anlamıyla yeterli olmadığı bir durumda, dijital ortamlarda paylaşım yapan birçok sosyal medya kullanıcısı yapılan paylaşımların kendileri sildikleri takdirde sonsuz bir şekilde dijital ortamlardan silindiğini düşünmekte, ileri zamanlarda kendisinin karşısında nereden çıkacağını bilmeden, hiç düşünmeden mahremiyetlerini ihlal eden paylaşımlarda bulunmaktadırlar.

Sosyal medya ortamlarında yapılan paylaşımların yaratacağı olumsuz etkileri düşünmeden kullanıcı sayısının her geçen saniye arttığı dijital dönemde toplumun mahremiyet anlayışını Naci İspir bu sözlerle dile getirmiştir (İspir, 2018: 767); Mahremiyet toplumun değer yargılarıyla tanımlandığı için toplumdaki değer yargıları değiştikçe mahremiyet algısı da değişmektedir. Fakat gelişen teknoloji ile iletişim kurma yöntemleri de değişerek sosyal eğilimlere etki etmiş sonuç olarak da sosyal medya ortamları bireylerin hayatlarının merkezi durumuna gelmiştir. Sosyal paylaşım ağlarının var olma nedenleri sosyal görünürlülük olmakla birlikte mahrem ve özel alan probleminin tekrar gözden geçirilmesi gerekliliğini ortaya çıkarmıştır. Özel olanı kamusallaştırmanın bir yönü olduğuna inanılan veya olmak istenen kimlik ile sanal ortamda bir görünürlügün oluşturulması ile yaşanan mutluluk, sanal ortamda aktif olmanın toplumdaki kabul görme ile bir tutulması, diğer bir yönü de içeriğin aslında bedensel olan bir kimliğe değil de sosyal bir ağa, bir hesaba yani dijital bir ortama ait olmasıdır. Teknoloji kusursuzlaştıkça ve egemenlik alanı genişledikçe sanal olan gerçeklik kazanmakla birlikte kişiye toplumsal değer yargılarından, yaptırımlardan uzak -gözetleme ve gözetlenme bakımından- sınırsız bir özgürlüğün anahtarını vermektedir. Bu durumda da aslında mahremiyetin ihlali değil gönüllü bir ifşanın var olduğu söylenebilir.

\section{Amaç ve Yöntem}

Çalışma, geleneksel aile toplantılarının gözdesi olan, kişinin en mahrem anlarının yer aldığ 1 ve en mahrem alanlarında en özel kişilerle paylaştığı, geçmişini ve yaşadığ 
anını ölümsüzleştirerek gelecek nesillere aktarılabilen kültürel bir miras olarak da değerlendirilebilecek fotoğraf albümlerinin mahrem olmayan kamusal alanlarda nasıl paylaşıldığını Instagram örneği üzerinden paylaşılan fotoğraflarla yorumlayabilmeyi amaçlamaktadır. $\mathrm{Bu}$ örneklerden hareketle kişinin toplumsal mahremiyet algısında yaşanan dönüşüm, gizlenen, saklanan mahrem olan özel anların kişinin kendi rızasıyla -benliğini gerçekleştirme ve beğenilme arzusuyla- kamusal alana ne şekilde taşındığını açiklayabilmek amaçlanan bir diğer önemli husustur.

$\mathrm{Bu}$ amaçlar çerçevesinde çalışmada yöntem olarak nitel araştırma yöntemi olan doküman analizi yöntemi kullanılmıştır. Nitel veri ile çalışmayı gerçekleştiren kişi okuyucuya gerçekçi ve betimsel bir tablo sunmayı amaçladığ için nitel verinin ayrıntılı olmasının yanı sıra belirli bir derinliğe de sahip olması gerekmektedir (Aktaran: Özdemir, 2010: 327). Bu yöntemle literatür kapsamında anlatılanları açıklayabilme kapasitesi bakımdan en ayrıntılı ve derinlemesine incelenebilecek verileri içeren bir fotoğraf paylaşım sitesi olan Instagram üzerinden rastgele yöntemle seçilen çocuk, aile, evlilik, doğum, iş, maddi olanaklar, beden gibi en mahrem anların fotoğrafları seçilerek mahremiyet algısındaki dönüşüm analiz edilmeye çalışılmıştır.

Doküman analizi nitel araştırma yöntemlerinde en çok kullanılan veri toplama tekniklerinden bir tanesidir. Corbetta'ya göre dokümanlar birbirinden tamamen farklı olan iki türden oluşmaktadır. Bunlardan biri, şirket belgeleri, konuşmalar, gazete makaleleri, duruşma tutanakları vb. dokümanları içerin kurumlar tarafından ya da kurumsal rolleri bağlamında tek tek bireyler tarafından üretildikleri için kurumsal belgeler olarak nitelendirilen verilerdir. Bu belgeler genellikle kamusal niteliktedir. Bir diğer doküman türü ise mektuplar, günlükler, otobiyografiler, fotoğraflar, videolar vb. dokümanlardan oluşan kişisel belgelerdir. Kişisel belgeler, bu belgelerin özel doğasının yani tek tek kişiler tarafından kesinlikle "kişisel”" kullanım için üretildikleri gerçeğinin altını çizmek için kullanılır; aynı zamanda bu belgeleri üreten bireylerin duygularını, yapmış oldukları işleri, daha genel olarak kişiliğini ifade ettikleri için "ifade edici" belgeler olarak da adlandırılmaktadır (Corbetta, 2003: 288). Çalışmada Corbetta'nın yapmış olduğu bu ayrıma göre kişisel bir doküman olan fotoğrafların analizi yapılmıştır. Ancak literatür çerçevesinde mahremiyetin yaşadığı dönüşüm ile sosyal medyada paylaşılan fotoğrafların kamuya açılmasından dolayı özel/kişisel bir belge olmaktan çıktığını tıpkı kurumsal belgeler olarak nitelendirilen kamusal nitelikte olan belgeler ile benzer özellikler taşıdığını söylemek mümkün olmaktadır.

Çalışma kapsamında analiz edilmek üzere gruplandırılmış her bir ayrı mahremiyet alanı için Instagram uygulamasında o alan ile ilgili en çok paylaşım yapıldığı düşünülen hashtag (\#) ile arama yapılmış ve çıkan sonuçlar arasından olasılıklı örnekleme yöntemlerinden "basit rastgele örnekleme yöntemi” ile seçilen görseller tercih edilmiştir. Seçilen bu örnekler internette arama yapan herkesin görebileceği şekilde kamuya açık olduğu için bilimsel bir çalışma için kullanılmasında bir sakınca görülmemiştir ancak yine de kişilerin kendi rızalarıyla teşhir ettiği ve kamusallaştırdığı paylaşımlar olmasına rağmen kişilerin yüzleri ve hesap bilgileri sansürlenerek verilmiştir. Aynı zamanda kişilerin mekân paylaşımlarındaki işletme bilgileri, fotoğraflara yorum yapan kişilerin de hesap bilgileri sansürlenmiştir. 


\section{Bulgular}

Teknolojik gelişmeler ve internet kullanım ağının genişlemesiyle birlikte günümüzde "kişisel verilerin güvenliği” bir sorun olarak sık sık karşımıza çıkmaktadır. "İnternet kullanım alışkanlıklarımız, verilerimizin güvenliğini, mahremiyetimizi acaba ne derece tehdit ediyor?" sorusu zihnimizin bir tarafında sürekli bizi uyarıp tedirginlik yaratıyorken bir taraftan da bu soru hiç aklımızda değilmiş gibi sosyal medya ortamlarında yaptığımız paylaşımlarla kendi rızamızla mahremiyetimizi ihlal ediyoruz.

$\mathrm{Bu}$ bağlamda aslında kişisel verilerin korunması hususunda en etkili öğe kişinin kendisi olup sorumluluk ona aittir. Kişisel veriler paylaşılmadan önce aydınlatma metni varsa eğer açık rıza metni dikkatli bir şekilde okunmalıdır. Bireyler, kişisel verilerin istendiği uygulamalara karşı daha dikkatli olmalı ve bu uygulamaların güvenli olup olmadığ sorgulanarak araştırmalıdır. Sosyal medya ortamlarında hangi paylaşımları kimlerin göreceğini belirlemek kişisel verilerin korunabilmesi adına önemli ve gerekli olan bir husustur. Kişilerin çevrimiçi veya gerçek ortamlarında oluşabilecek mahremiyet ihlallerine karşı bilgi sahibi olmaları gerekir. Güvenliğe açılan kapının kilidi farkındalık olduğu için kişisel verilerin korunması hususunda farkındalık kazanmak çok önemlidir (Bilir, 2021: 176). Sosyal medya ortamlarında mahremiyet alanını deşifre ederek yapılan birçok paylaşım ile farkındalık oluşmadığı çalışmanın bulgularında mahremiyet ihlali olarak karşımıza çıkmaktadır.

\section{Aile Birlikteliği "Yemek Masaları"}
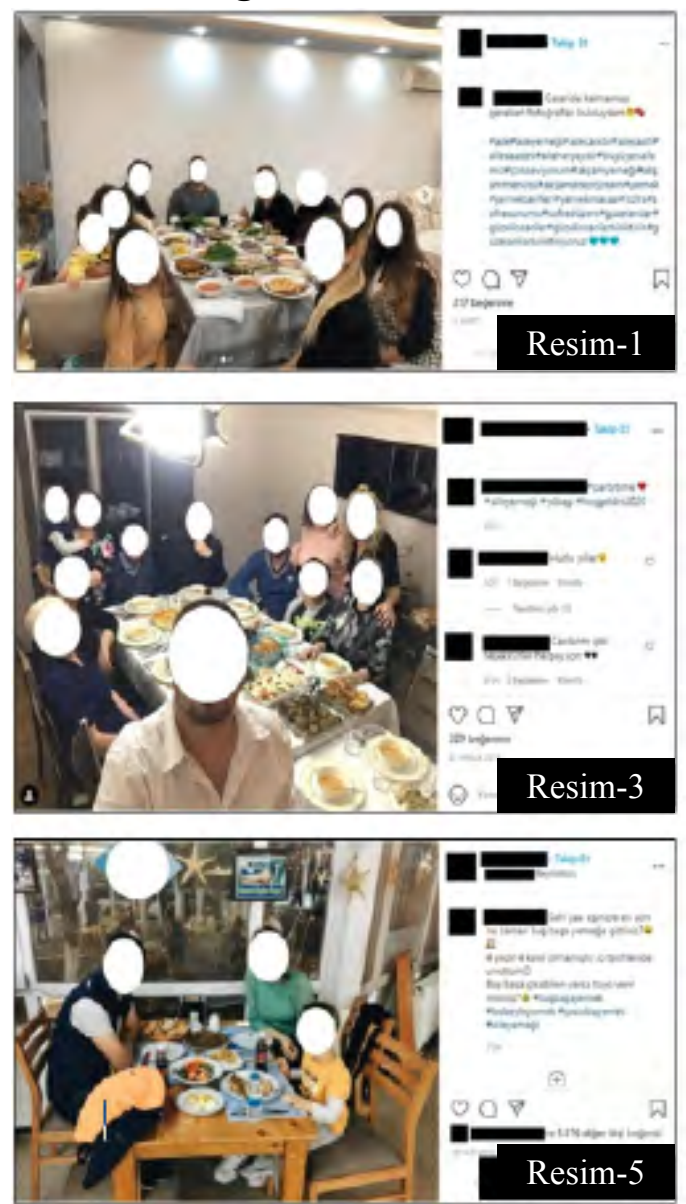
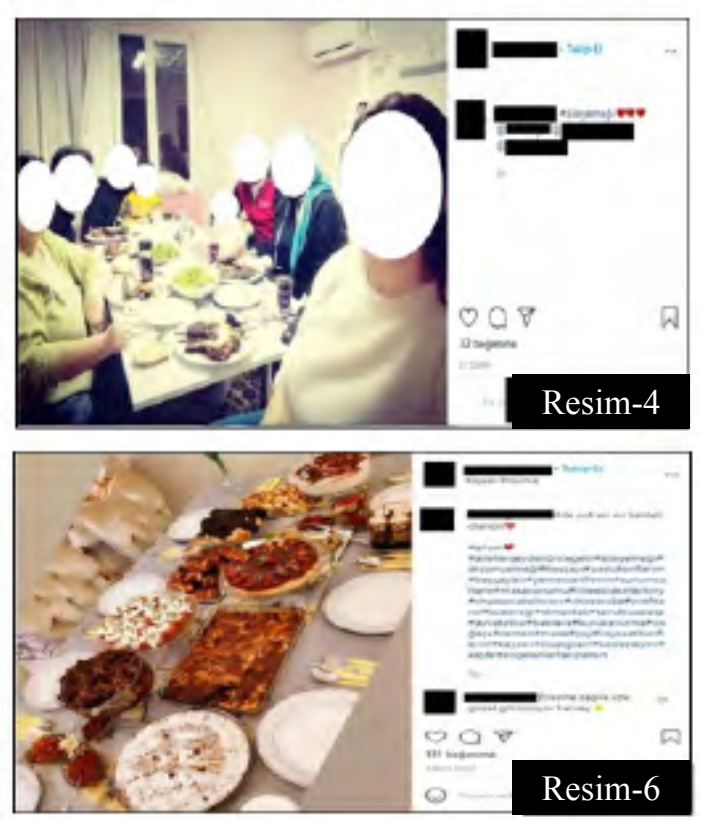
Aile fotoğrafları geçmişten günümüze aile bağlarını güçlendiren, ailenin geçmişini tarihsel bir miras gibi genç üyelerine aktarımını sağlayan belgelerdir ve bu belgeler ilk zamanlardan beri mahrem alanlar içerisinde paylaşılırken günümüzde hiç tanımadığımız insanların bile görebileceği şekilde paylaşılmaya başlanmıştır. Bu paylaşımları yapan kişiler bu durumdan hiç de rahatsız olmadan kendi rızalarıyla gerçekleştirmektedirler.

Ailenin yapısal dönüşümü ve modernleşme süreci ile birlikte bellek oluşturma hevesinin etkisiyle aile fotoğrafları tarihsel süreç içerisindeki etkisini sürdürmüştür. $\mathrm{Bu}$ anlamda hem kültürel hem de toplumsal bakımdan incelenmesi gereken aile fotoğraflarının işlevleri şu şekilde sıralanabilir (Erkonan, 2014: 127); Aile fotoğrafları, kamusal ve özel alanın yapısı ile ilgili bilgi vermekle birlikte kamusal alanın özel alana yansıyan ortak noktalarını açıklayabilen toplumsal belge niteliği taşımaktadır. Aile fotoğrafları aileyi kurumsal ve imgesel olarak destekleyerek aile imgesinin oluşturulmasında rol oynar. Aile fotoğrafları çekildiği zaman ve mekânla birlikte kurgulanarak aile yaşamının ve belleğinin yani ailenin var olduğunun ispatlandığı bir hikaye sunar.

Aile fotoğrafları, var olma nedenleri ve geleceğe bırakılan bir miras olması bakımından bu kadar önemli işlevlere sahip iken bu kadar mahrem olan bir alanın nasıl kamusal bir alana dönüştüğü incelenen aile yemeklerinin yer aldığ1 fotoğraf paylaşımlarında da görülmektedir. \#aileyemeği hashtagi ile yapılan arama sonucunda listelenen 9.175 paylaşım arasından rastgele örneklem yöntemiyle seçilen fotoğrafların genel özelliği aile birlikteliğinin simgesi olan yemek masalarında çekilmiş olmalarıdır.

Resim 1'de "Galeride kalmaması gereken fotoğraf bulduysam" açıklaması ile paylaşım yapan kullanıcı, birçok farklı hashtag kullanarak kamuya açık bir şekilde paylaştı̆g 1 aile mahremiyetini daha da fazla kişinin görmesinde bir sakınca görmemiştir. Fotoğrafta aile mahremiyetiyle birlikte aile üyelerinden birinin çocuk olması sebebiyle çocuk mahremiyeti de ihlal edilmiş aynı zamanda en mahrem alan olan ev mahremiyeti de kamusal bir meta haline dönüştürülmüştür. Resim 2'de 'Can'ımız İstanbul'dan geldi hoş geldi..." açıklamasına ek olarak farklı dillerde "iyi geceler ve hashtag" yazımıyla mahremiyetin ulusal değil uluslararası düzeyde beğeni alması hedeflenmiştir. Selfie olarak yapılan bu paylaşımda kişilerin mahremiyetinin yanı sıra evin büyük bir bölümünün fotoğrafa yansıması, açık olan televizyonda tercih edilen kanalın yansıması ile mekân ve özel hayat mahremiyetinin de ihlal edildiği görülmektedir.

Resim 3'te 2020 yılbaşı yemeği olduğunu belirten farklı dilde de yapılan hashtagler ve selfie tarzında bir paylaşımla aile yemeği mahremiyeti ifşa edilmiştir. Yine bir çocuğun fotoğrafta yer alması sebebiyle çocuk mahremiyeti de ihlal edilmiştir. "Canlarım çok teşekkürler her şey için" yorumuyla o masada olan bir kişi olduğu düşünülen bireyin memnuniyetinin özel alan dışında kamusal alana dönüşen sosyal medya ortamında da yapması birçok farklı paylaşımda da benzer durumun olması nedeniyle sosyal medya örflerinden olduğu söylenebilir. Örf ve adetlerimizin de sanal ortama taşınma noktasında bir dönüşüm yaşadığı görülmektedir. Resim 4'te de yine aile yemeğini kamusallaştırmak isteyen kişinin selfie ile yapılan fotoğrafının masadaki diğer insanları da etiketlemek suretiyle onların da kişisel mahremiyetini ifş̧a eden paylaşımda yine mekân ve çocuk mahremiyetinin ihlali söz konusudur. 
Resim 5'te ise diğerlerinden farklı olarak aile yemeği, ev mahremiyetini ihlal ederek değil de dışarıda bir mekânda çekilen bir fotoğrafla kamuya sunulmak istenmiştir. Ailesi ile yediği sevgi dolu bir yemeği "Sahi yaa eşinizle en son ne zaman baş başa yemeğe gittiniz?.." notuyla paylaşan kullanıcı çocuğunun bireysel mahremiyetini ihlal etmekle kalmayıp çocuğunu kamusal bir sorun olarak yansıtmayı tercih etmiştir. Resim 6'da ise bir aile yemeği öncesi özenle hazırlanan sofra kişiler olmadan paylaşılmak istenmiş ve birçok hashtagle de desteklenmiştir. Mahremiyetini kamusal alana açan kullanıcı \#keşfettengelenlertakipetsin hashtagiyle diğer kullanıcıları davet eder nitelikte takipçi sayısını artırmak için bir girişimde bulunmuştur. Hayatın en mahrem alanı olan aile ve ev mahremiyetinin ihlal edildiği bu paylaşımlarda masadaki yemeklerin de -o masayı görecek kişilerin maddi imkânlarını bilmeden- paylaşılmasında hiçbir sakınca görülmemesi toplumsal örf ve adetlerin de nasıl dönüştüğünün kanıtıdır.

\section{Masumiyetin İhlali}
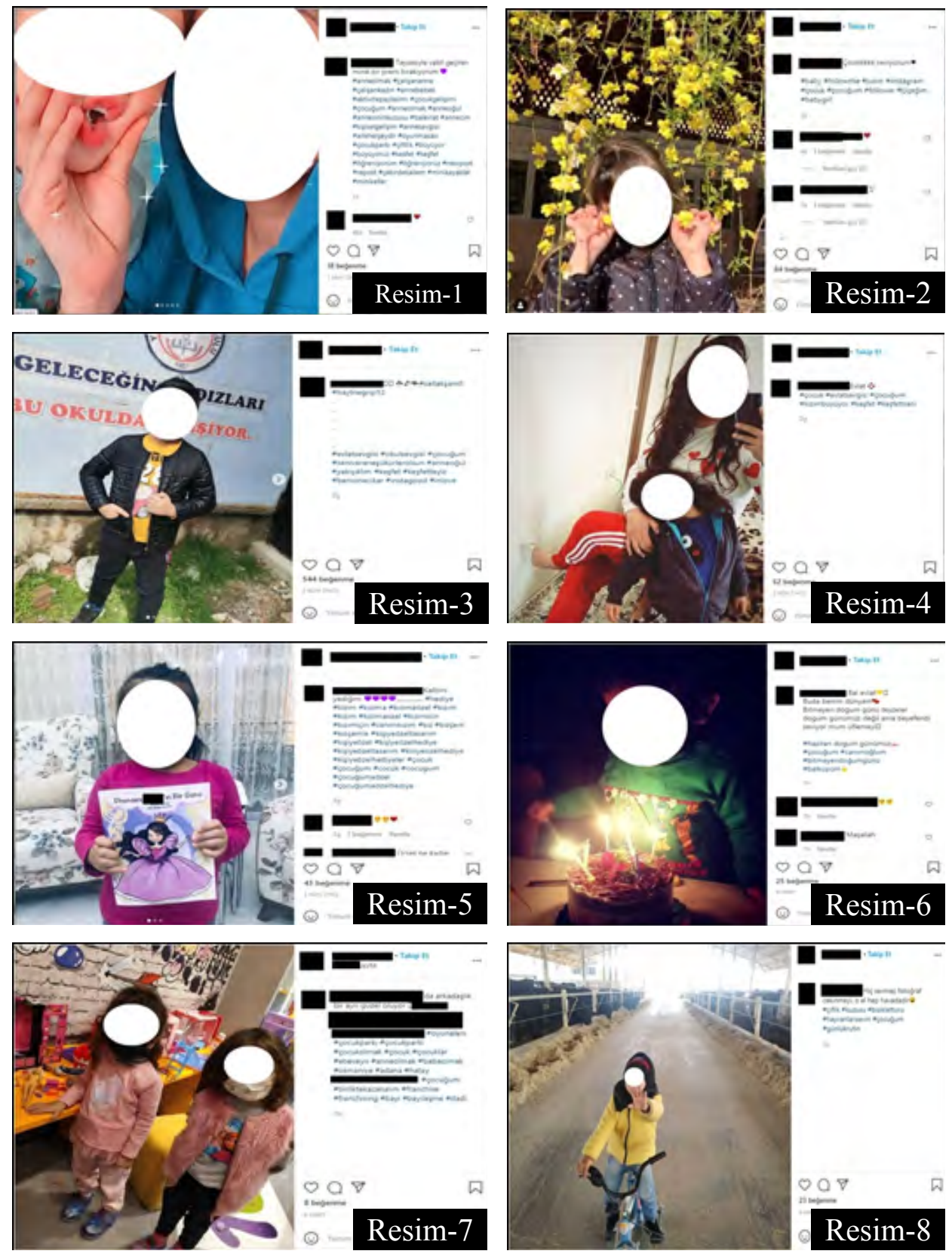
Mahremiyet ihlalinin üzerinde en çok konuşulan tartışılan bir alanıdır, "çocukların masumiyeti"nin sosyal medya ortamlarında deşifre edilmesi suretiyle ihlali. Çünkü bu fotoğrafların paylaşımı tamamen çocukların iradesi dışında gelişen bir durumdur. Üstelik çocuk mahrumiyetinin ihlali çok çeşitli şekillerde olabilmektedir; ebeveynleri, akrabaları, bazen kendileri, katıldıkları herhangi bir etkiliğin (dans, müzik, atölye çalışması vb.) yetkililerinin paylaşımı, gittikleri okullardaki öğretmenleri, okul yetkilileri çocukların fotoğraflarını sosyal medya ortamlarında paylaşarak masumiyetlerini ve haklarını ihlal etmektedirler.

Yukarıda yer alan 8 paylaşım Instagram'da \#çocuğum hashtagiyle paylaşılan 30.794 fotoğraf arasından rastgele yöntemle seçilmiştir. Arama sonucunda sıralanan fotoğraflarda çocukların genelde tek başına oldukları fotoğraflaryer alırken bazılarında da biryakınlarıyla birlikte çekilmiş fotoğraflar yer almaktadır. Resim 1'de kullanıcı tarafından "Teyzesiyle vakit geçiren minik bir prens bırakıyorum." notunun altında yer alan çok sayıda hashtag ile paylaşılmış bir fotoğraf yer almaktadır. Hashtag sayısının fazla olması genellikle kişilerin o hashtag ile yaptığı arama sonucunda kendi fotoğraflarının da sıralanması ve bu sayede takipçi sayısını artırmak amacıyla yapıldığını söylemek mümkündür. Fotoğraftaki \#anneolmak, \#çalışananne, \#anneolmak, \#anneoğul, \#annesininkuzusu, \#balevlat vs. hashtaglerinden paylaşımı yapan kullanıcının fotoğrafta yer alan çocuğun annesi olduğu anlaşılmaktadır. Çalışan bir anne olan kullanıcının bu paylaşımıyla, annesi işte olan çocuğun teyzesiyle birlikte geçirdiği vakti kamusallaştırarak beğeni toplaması amaçlanmıştır. Teyzesinin yanaklarını sıkmak suretiyle çocuğun yüzünün aldığı şekil ile çocuk sevimleştirilmek istenirken çocuğun yaşının ilerlemesi ile birlikte bu durumdan hoşlanmama ihtimali göz önünde bulundurulmadan mahremiyeti ihlal edilmiştir. Resim 2 'de yine annesi tarafından paylaşımı yapılan bir kız çocuğunun fotoğrafi yer almaktadır. Çocuğun ellerinde ağacın dallarından sarkan sarı çiçeklerle birlikte gülümsemesi eşliğiyle sevimli bir görüntü çizilmeye çalışılmıştır. Fotoğraf "Çookkkkk seviyorum." notu ve farklı dillerdeki hashtagler ile paylaşılarak daha uluslararası düzeyde bir beğeni alması istenmiştir. Fotoğrafa yakını olduğu düşünülen kişiler tarafından yorum yapılarak sevginin sıcaklığı sanal ortamın soğuk yüzüyle kaplanmıştır.

Resim 3'te çocuğu okula giden bir annenin okulun önünde çekilen bir fotoğraf paylaşımının yapıldığı görülmektedir. Paylaşım iki farklı dilde bazı hashtagler ile paylaşılmış olup evlat sevgisi ve okul sevgisi vurgusu yapılırken \#keşfet, \#keşfetteyiz, \#benionecikar hashtagleriyle paylaşımın amacının daha fazla takipçi tarafından takip edilip beğenilmek olduğu görülmektedir. Nitekim 544 beğeni alan paylaşımın bu amaca ulaştığını söylemek mümkündür. Ancak çocuğun mahremiyeti ihlal edilmek suretiyle beğeni almak ve takipçi artırma isteği güdülmesi büyük bir sorunsaldır. Resim 4 'te 3 mahremiyet alanının aynı fotoğraf karesinde ihlal edildiği görülmektedir. Kızıyla olan fotoğrafını paylaşa anne bireysel mahremiyetini, çocuğunun mahremiyetini ve evinin mahremiyetini ihlal etmektedir. Yine hashtaglerle yapılan paylaşımda kullanılan \#keşfet, \#keşfettreni hashtagleri ile bir önceki paylaşımda olduğu gibi aramalarda öne çıkmak planlanırken 52 beğeniyle onun kadar şanslı(!) olmadığ 1 görülmektedir.

Resim 5 ve Resim 7'de akraba, ebeveyn gibi yakınlığı olmayan başka hesaplar tarafından paylaşılan çocuk fotoğrafları yer almaktadır. Resim 5'te kişinin ismine özel 
hazırlanan kitabı alan çocuğun sevincinin yer aldığı bir fotoğraf yer alırken burada kişinin çocuğun hem beden hem de isminin deşifre edildiği bir paylaşım söz konusudur. Burada amaç daha fazla beğeni ile takipçi sayısını artırarak siparişlerin artması ve para kazanılmasıdır ki çocuk mahremiyetinin ekonomik çıkarlar güdülerek ihlal edilmesi toplumsal yozlaşmanın gerçek bir kanıtıdır. Resim 7'de de yine aynı şekilde ticari bir kaygıyla bir alış veriş merkezindeki çocuk atölyesine katılan iki çocuğun görüntüsü yer alarak hem merkezin hem de atölyenin reklamı yapılmaktadır.

Resim 6 ve Resim 8'in ortak noktası ise, takipçileriyle karşılıklı bir iletişim içerisindeymiş gibi yapılan sunum. Resim 6'da "Bitmeyen doğum günü teyzeler..." notuyla pastadaki mumu üfleyen bir çocuk, Resim 8'de ise "Hiç sevmez fotoğraf çekinmeyi, o el hep havadadır..." notuyla paylaşılan fotoğrafta çocuk mahremiyetinin yanı sıra bir de bu durumdan hiç hoşlanmayan mutsuz bir çocuğun fotoğrafının ısrarla annesi tarafından paylaşılması da mahremiyetin daha da ileri bir noktasıdır.

Bütün bu paylaşımlardan hareketle, özellikle de çocuklarının yakınları, ebeveynleri tarafından psikolojik tatmin, sosyal kabul ya da maddi kazanç sağlamak adına çocuklarını adeta yetişkin bir birey gibi sunmaları çok ciddi etik problemleri barındırmaktadır. Çünkü ebeveynler mahrem alan içerisinde korunmaya muhtaç en masum canlı olan çocuklarının mahremiyetini yabancı olan herkesten korumakla yükümlüyken (Soncu, 2020: 316) aksine kendi çocuklarını kendileri kamusal bir meta haline dönüştürmektedirler.

\section{Duvak'ın Masumiyeti'nin İhlali}
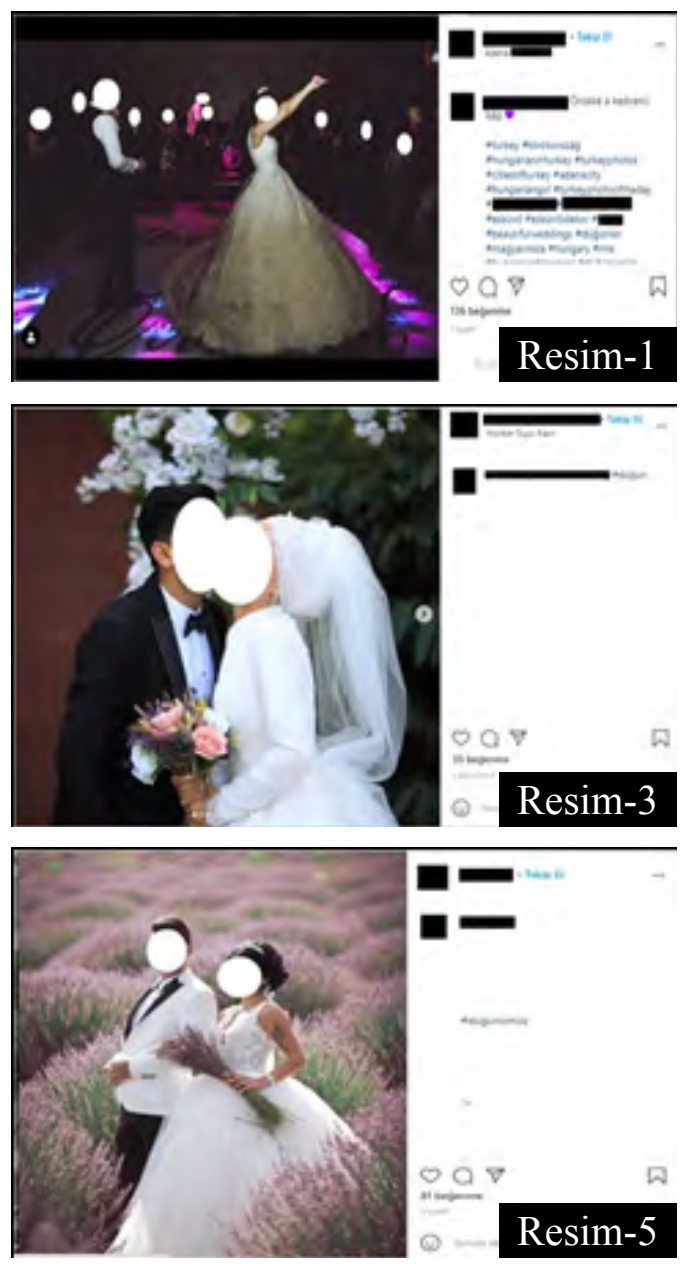
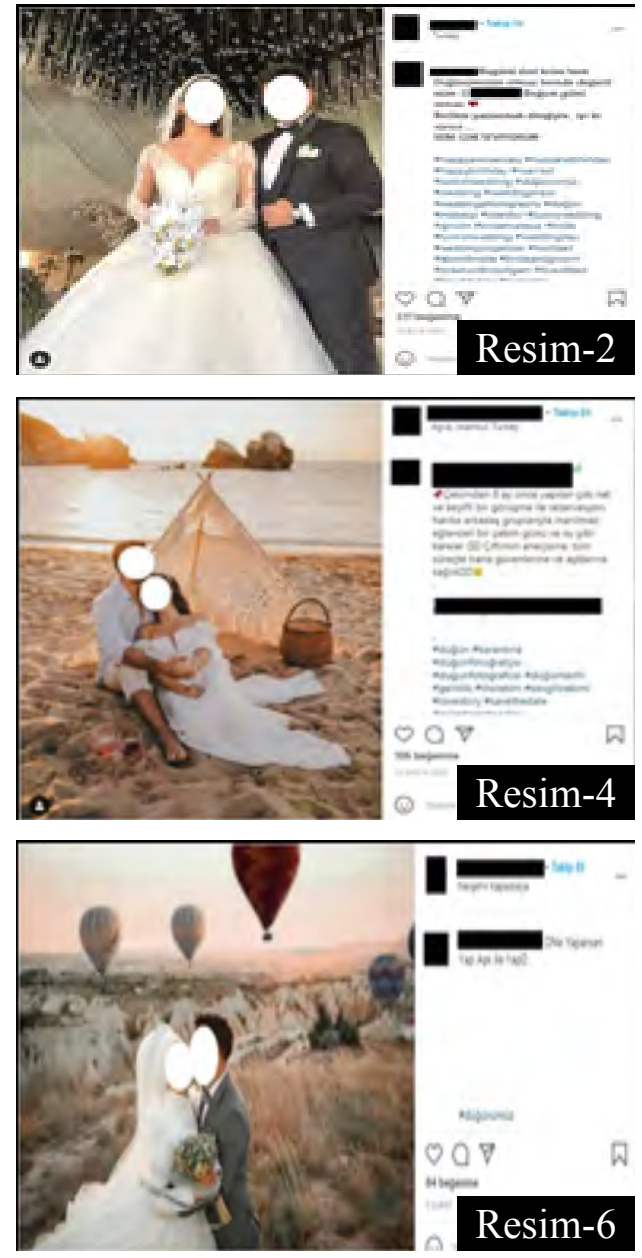
Sosyal medya ortamlarında paylaşım yapılmak suretiyle en çok ihlal edilen mahrem alanlardan biridir gelin-damat fotoğrafları. Bireyler en mutlu oldukları ve sosyal bir statü kazandıkları gün olarak gördükleri düğün anlarıyla ilgili fotoğraflarını sosyal medya ortamlarında paylaşarak hem bu mutlu günlerini kamuya duyurmak hem de kişinin kendini en özel hissettiği anlardan biri olan gelinlik ve damatlıkla çekilen fotoğraflarını beğeni alarak psikolojik olarak bir tatmin yaşamak istemektedirler. Bu amaçla, Instagram uygulamasında \#düğünümüz hashtagiyle yapılan arama sonucunda görüntülenen 38.493 fotoğraf arasından seçilen 6 fotoğrafin yorumlanması yapılmıştır.

Paylaşımların geneline bakıldığı zaman fotoğrafçılar tarafından paylaşılan çiftlere ait dış çekim fotoğraflarının yer aldığı görülmüştür. Popüler kültür bağlamında "düğün fotoğrafçılı̆̆ı" olarak kavramsallaştırılan mesleki terimin varlığı söz konusudur. Fotoğrafçılar tarafından paylaşım yapılmasının amacı kendi çektikleri örnekleri sunarak potansiyel müşteriyi kendilerini tercih etmeleri konusunda uyarabilmektir. Genelde birbirinin tekrarı niteliğinde olan düğün fotoğrafları için farklıyı arama üzerine odaklanılan bir popüler davranış biçimi sergiledikleri görülmektedir. Durum böyle olunca da yaratıcılığı tetikleyen bir yaklaşım tarzı ortaya çıkmaktadır (Tumay, 2018: 13). Düğün fotoğrafçıları tarafından yapılan paylaşımlarda da bu net bir şekilde görülmektedir. Resim 3,4,5 ve 6'da fotoğrafçılar tarafından yaratıcı yönde yapılan çalışmalarla kişilerin en özel anlarından biri olan düğün anları ölümsüzleştirilmiştir. Fotoğraflarda özellikle gözde popüler kültür mekânları olan lavanta bahçesi, Kapadokya, deniz kenarı gibi aşkın duygusunu yansıtabilecek dış mekânlar tercih edilmiştir. Resim 4'te özellikle deniz kenarında kurulan makrome çadır, hasır sepet ve iki kadeh ile baş başa huzurlu bir ortamda aşkın masumiyeti imgeleştirilmek istenmiştir. Bütün bu paylaşımlarla geçmişten günümüze mahrem olarak gelen en önemli anlardan biri olan düğün anları kamusal alanlara taşınarak psikolojik tatmin ve özel alanlarda yapılan çekimlerin belli bir bütçesi gerektirmesi nedeniyle sosyolojik olarak toplumsal bir saygınlık kazanılması da söz konusu olmaktadır. Çünkü fotoğrafçılar bu paylaşımları çiftlerin rızasını alarak yapabilmektedirler.

Resim 1 ve 2 diğerlerinden farklı olarak kişilerin kendilerinin yaptıkları paylaşımlardır. Resim 1'de düğün anından bir dans sahnesi, mekân da belirtilerek paylaşılmıştır. Bu paylaşımda kişinin sadece kendi mahremiyeti değil kadraja giren diğer davetlilerin de mahremiyeti ihlal edilmiştir. Resim 2'de de eşinin doğum gününün düğünüyle aynı güne denk gelmesi ile sevgisini sosyal medya ortamında dile getirmeyi tercih eden kişinin paylaşımıyla özel hayatlarının mahremiyetinin ihlalinin söz konusudur.

Doğum Mahremiyeti
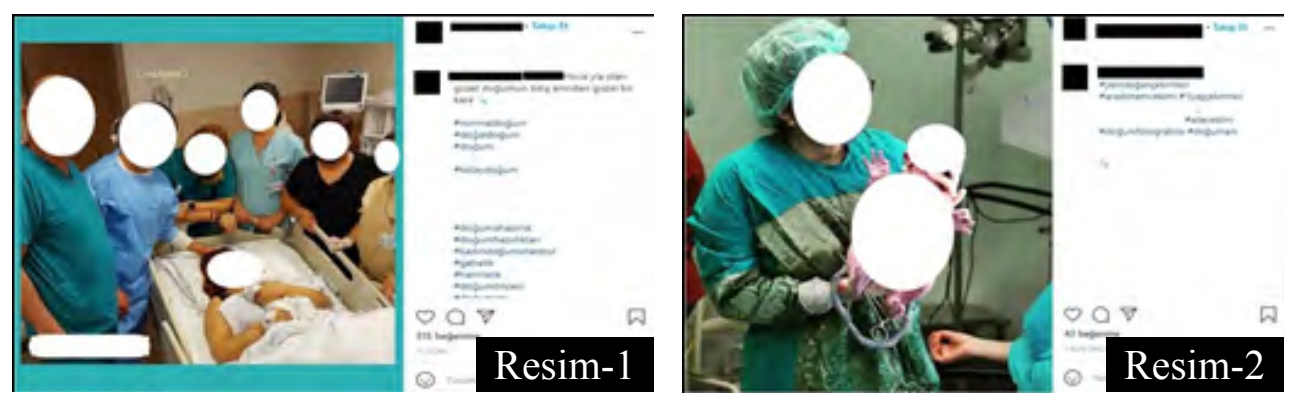

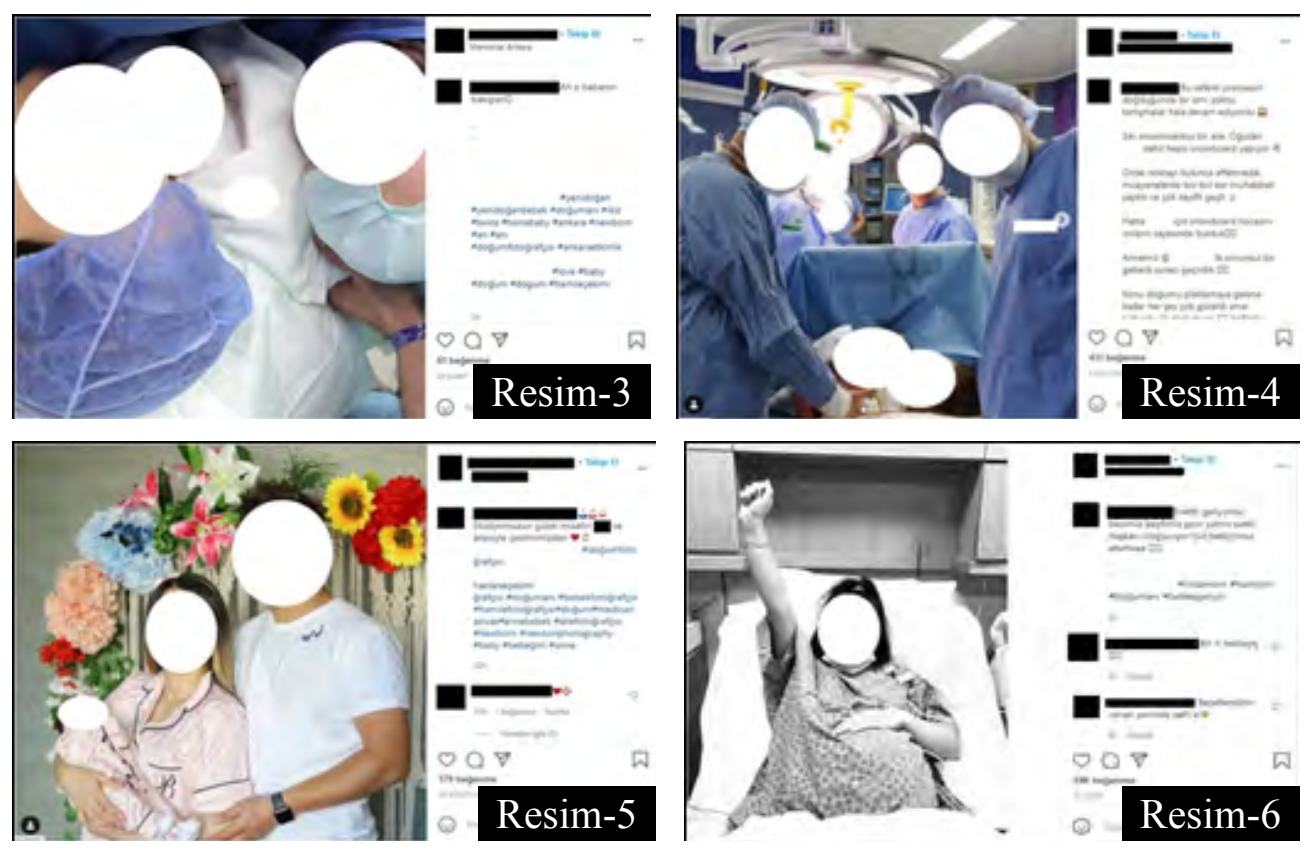

Doğum anı da diğer mahremiyet alanları gibi kişinin en gizli kalması gereken özel hayat alanlarından bir tanesidir. Ancak sosyal medya ortamlarında yapılan paylaşımlarla kişi dünyaya geldiği ilk andan itibaren dijital alanda gözetlenerek hayata gözlerini açmaktadır. Bu noktada da hem doğum yapan annenin hem de masumiyetin simgesi bebeklerin mahremiyetleri ihlal edilmektedir. Özellikle de tıpkı düğün fotoğrafçılığı gibi doğum fotoğrafçılığı kavramının da sektörde yerini almasıyla kişiler nerdeyse hamile olduklarını öğrendikleri andan itibaren doğum günü fotoğraf çekimi için bu alanda hizmet veren fotoğrafçıların kapısını çalmaktadırlar. Çalışma kapsamında da Instagram uygulamasında \#doğumanı hashtagi ile yapılan arama sonucunda listelenen paylaşımlar arasından basit tesadüfi örneklem yöntemiyle 6 fotoğraf tercih edilmiştir. Paylaşılan fotoğrafların genelinde doğumun gerçekleştiği ameliyathanede çekilen fotoğraflar yer almaktadır. Nitekim Resim 1,2,3 ve 4 de bebeğin dünyaya geldiği ilk andan itibaren kendi iradesi dışında mahremiyetinin ihlal edildiği bir dünyaya gözlerini açtığı görülmektedir.

Resim 1, doğumda ebe olarak yer alan kişinin “... Hoca'yla olan güzel doğumun bitiş anından güzel bir kare" notuyla paylaştığı fotoğrafta o ekipte yer alan bütün sağlık personelinin, annenin ve en önemlisi de bebeğin mahremiyeti -kişilerden izin alınarak paylaşılmış olsa dahi- ihlal edilmiştir. Ebeliğin doğum öncesi süreçten başlayarak doğum anı ve sonrası devam eden özel bir hizmet haline dönüştüğü günümüzde eklenen hashtglerle de ebenin tanınırlığını artırarak daha çok kişiye ulaşabilme amaçlı yapılmış bir reklam çalışması olduğu düşünülebilir. Resim 2 ve 3 o özel anı ölümsüzleştirmek isteyenlerin doğum fotoğrafçıları tarafından yapılan çekimlerinin fotoğrafçı tarafından yapılan paylaşımlardır. Resim 2'de doğumun ilk saniyelerinde doktor tarafından bebeğin gösterildiği fotoğrafta bebeğin tüm mahrem alanları kamuya sunularak teşhir edilmiştir. $\mathrm{Bu}$ durum günümüzde maalesef $\mathrm{ki}$ artan taciz olayları düşünüldügüñnde, bebeğin masumiyeti ticari kaygı güdülerek linç edilmiştir. Resim 3 ve 5 'te ise fotoğrafçılar, aile bütünlüğünü göstererek aile kurumuna atfedilen değerin bebek ile güçlendiğini ve bu 
anların fotoğraflar aracılığıyla aktarılan eşsiz bir miras olduğu sunumuyla paylaşmıştır. Hatta Resim 3'te paylaşımda yer alan "Ah o babanın bakışları" notuyla desteklenerek o özel anı ölümsüzleştirmek isteyen herkesi fotoğrafçıların kapısını çalmaya teşvik edici olmuştur.

Resim 4 ise diğer ameliyathane fotoğraflarından farklı olarak gebeliği süresince takibini yaptığı bir hastanın anne olduğu ilk anını, takip süresince nasıl bir iletişimlerinin olduğunu anlattığ 1 bir notla paylaşım yapan doktora aittir. $\mathrm{Bu}$ paylaşımda doktor görsel olarak ameliyathane ekibinde yer alan sağlik personelinin, annenin ve bebeğin mahremiyetini ihlal etmenin yanı sıra paylaştığı notla hasta-hekim iletişimindeki mahremiyeti de ihlal etmiştir. Hasta hekim ilişkisinde mahremiyetin korunması sadece hekim ile sınırlı olmayıp tedavi süresince her türlü müdahale hastanın mahremiyetine sayg1 gösterilerek yapılmalıyken hatta ölüm durumunun bile bu mahremiyeti bozamayacağ Hasta Hakları Yönetmeliği'nin 21. maddesinde belirtilecek (Arslan ve Demir, 2017: 197) kadar hassas bir durumken hastayla iletişimde bulunan doktor tarafından -hastanın rızası alınmış dahi olsa- paylaşım yapılması çelişkili bir durumdur. Resim 6 ise diğerlerinden farklı olarak fotoğrafta bebeğin olmadığı doğum öncesi anne adayının kendi paylaşımıdır. Fotoğrafta anne adayının sol eli karnında sağ eli ise yumruk halinde havada olması doğum anıyla ilgili herhangi bir korku veya tedirginliğinin olmadığının betimlemesidir. Bu görsellik “...sanki başkası doğuruyor biz bekliyoruz...” notuyla da pekiştirilmiştir. Ayrıca kullanıcı paylaşımdaki hashtaglerde yer alan \#instamom ile de anneliğini Instagramda deşifre etmek suretiyle kişilerin kendilerini öne çıkarma yarışında olduğu Instagram anneliği adaylığının bir nevi duyurusu yapılmaktadır. 596 beğeni de mahremiyetin ileri de sadece annenin kendisiyle kalmayacağını çocuğunun da mahremiyetini ihlal edeceğinin sinyallerini vermektedir.

\section{Bedenin Teşhiri “Canım Kendim!”}
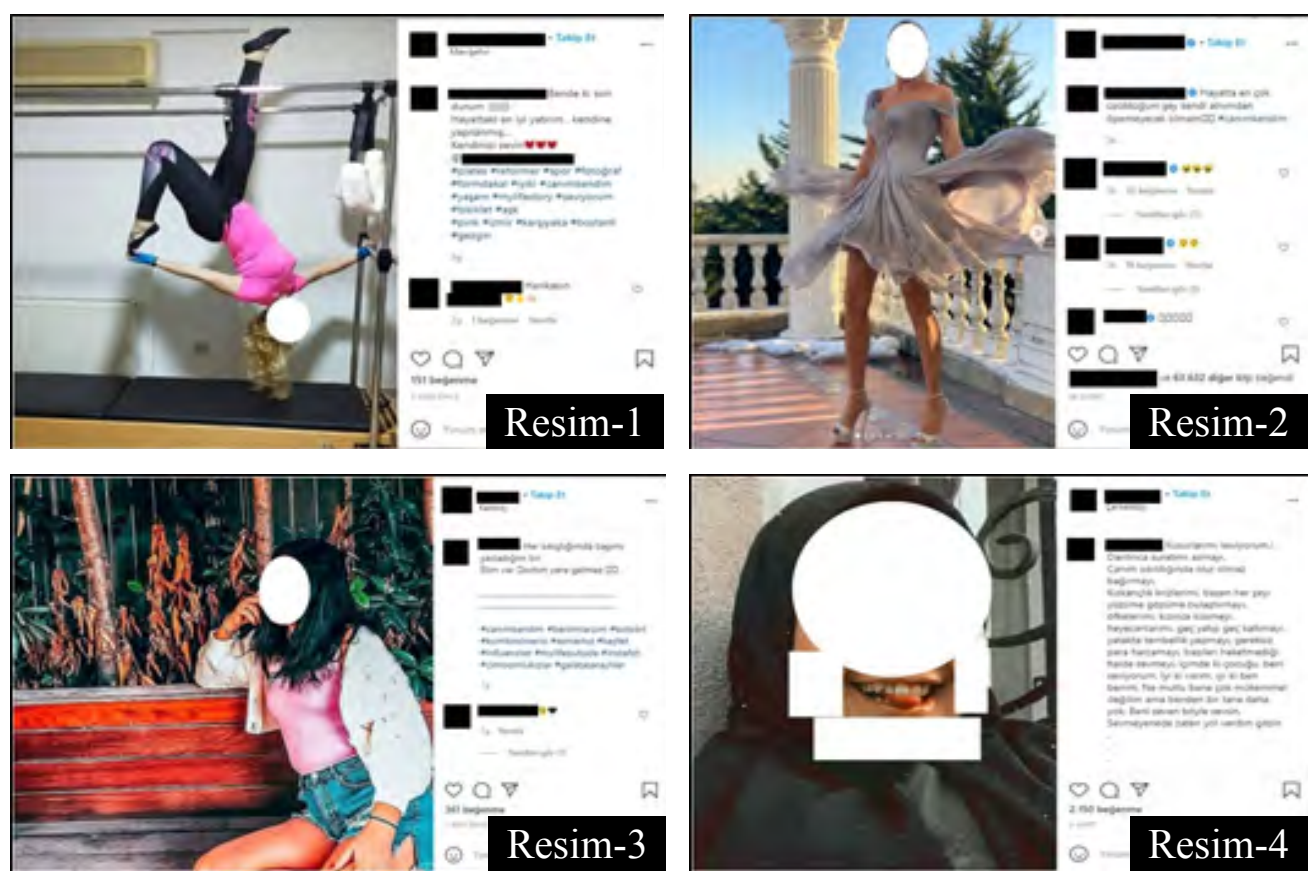

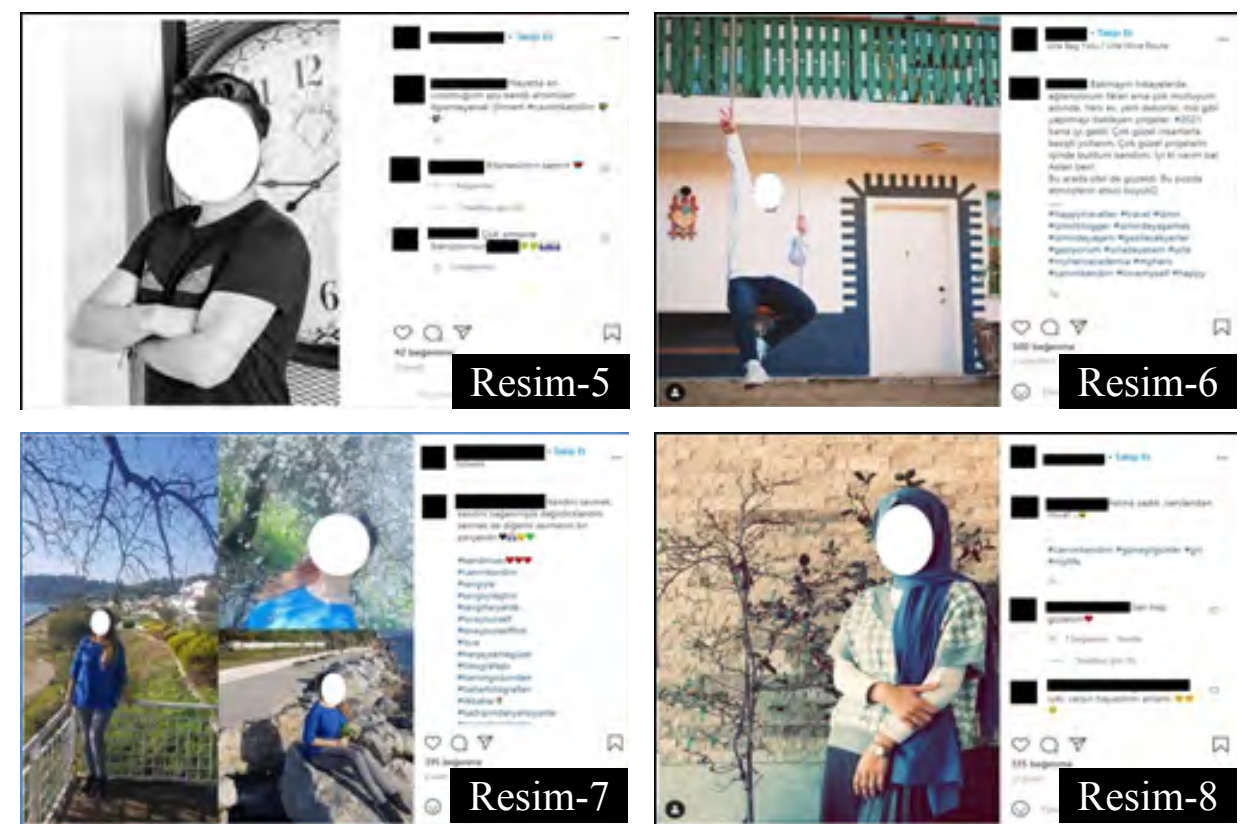

Dijital medya her bireyin kendisine özgü olmakla birlikte kişiye özel bir dünya sunmaktadır. Hiç kuşkusuz söylenebilir ki, dijital medya kişiye paralel bir evrenin kapılarını açarak orada hiç hayal bile edemeyeceği bir yaşam dünyasını mümkün kılmaktadır. Dijital medyanın bireye sunmuş olduğu bu yaşam dünyasının tanrısı da şüphesiz bireyin kendisidir (Anık, 2020: 156). Birey kendisi için bu ulaşılmaz görünen dünyayı kendi egosuyla bizzat kendisi yönetmektedir. Narsist bir kişilik yapısıyla kendini yücelterek toplumda saygınlık kazanma, üstünlük kurma bilinciyle sosyal medya ortamlarında paylaşım yapan insanların sayısı da her geçen gün artmaktadır. $\mathrm{Bu}$ paylaşımlarda bir kavram haline gelen \#canımkendim hashtagiyle paylaşım yapılan 31.657 fotoğraf arasından seçilen 8 görsel analiz edilmiştir.

\#canımkendim hashtagiyle paylaşım yapan kullanıcıların neredeyse tamamına yakını kadınlardan oluşmaktadır. Bu bağlamda Instagram uygulamasında kadınların başkaları tarafından beğenilme arzusunun erkeklere oranla daha baskın olduğunu söylemek mümkündür. Ayrıca bu ortamda kendini deşifre etme arzusunun, dininin emrettiği mahremiyet kurallarına uyan ancak sosyal medya ortamında bu mahremiyetini açığa çıkarmakta sakınca görmeyen kullanıcıları da kapsadığı görülmektedir. Nitekim Resim 4 ve 8 bu paylaşımlara birer örnektir. Özellikle Resim 4'te diğer paylaşımlarda sergilenen narsist kişiliğe ek olarak dilin dışarıda olması ile paylaşıma cinsellik öğesi de katılmıştır. Paylaşım, 2150 beğeni almıştır. Yine Resim 1, 2 ve 3 de dişiliğin ön plana çıkarılarak bedenin teşhiri ve mahremiyetin ihlal edildiği paylaşımlardandır. Resim 1'de pilates yaparken çekilen fotoğrafını "...Kendinizi sevin.." notuyla paylaşan kullanıc1, Resim 2'de "Hayatta en üzüldüğüm şey kendi alnımdan öpemeyecek olmam..." gibi hayatının odak noktasında sadece kendini konumlandıran bir kullanıcı profili görülmektedir. Aynı notu Resim 5'te yer alan paylaşımda erkek kullanıcının da yazdı̆̆ görülmektedir. İnsanın toplumsallaşma süreci içerisinde başkalarını ve kendinin diğer insanlar arasındaki konumunu belirlemesi kişinin benliğini tanımasını sağlamakla birlikte 
kişinin kendisini nasıl düşündügü ve hissettiği de benlik imajı ile alakalıdır. Benlik imajı güven ve güvensizlik kavramlarıyla çok yakından ilgilidir (Ertürk, 2010: 104). Bu kişilerin kendine olan güvenlerinden dolayı mı yoksa tam aksi güvensizliklerinden dolayı bu paylaşımlarıyla toplumsal bir kabul görme arzusunda mı oldukları psikoloji alanında incelemeler gerektirmektedir.

Kendini sevmek ile ilgili notların yazıldığı diğer paylaşımlardan Resim 3'te "Her sıkıştığımda başımı yasladığım bir elim var sırtım yere gelmez", Resim 6'da "İyi ki varım be! Aslan ben!", Resim 7'de "Kendini sevmek kendini beğenmişlik değildir, Kendini sevmek de diğerini sevmenin bir parçasıdır.", Resim 8'de ise "Aslına sadık, sanılandan muaf..." notları göze çarpmaktadır. Bütün bu paylaşımlardan hareketle sosyal medya ortamları kişilere kurgusal bir benlik oluşturabilme imkânı tanıdığı için bireylerin nazarında yüce bir durumdadır (Nacakc1, 2018: 260). Bu nedenle kişiler bu yüce(!) ortamda kendileri ve yaşam tarzları ile ilgili olarak bir kurgu yaratarak bu kurgunu başkaları tarafından görülmesine ihtiyaç duyan kişiliklere dönüşmüştür.

\section{Maddi Olanakların Sunumu}
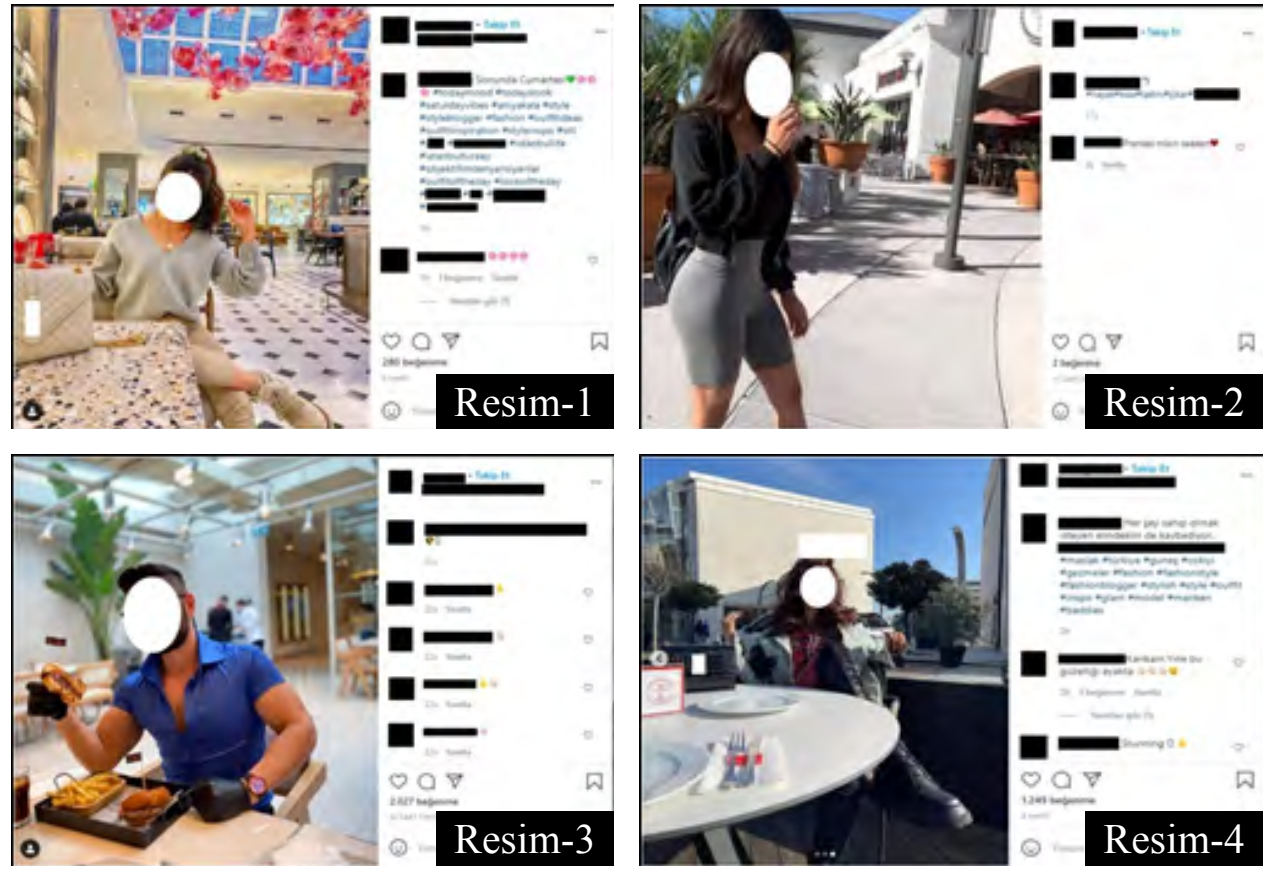

Instagram paylaşımlarında kişilerin bedenleri, özel anlarını teşhir etmelerinin yanı sıra en çok ihlal edilen bir mahremiyet alanı da variyetin ifşa edilmesidir. Eski zamanlarda yenilen, içilen, gidilen mekânlar, özellikle de lüks tüketim malzemeleriyse başka insanların bu imkânlara sahip olamadığı düşüncesiyle hassasiyetle gizlenirken şimdilerde ise gizlemek bir yana özellikle ifşa edilmektedir. Bunun yapılmasındaki temel amaç da maddiyatın toplumsal bir statü ve saygınlık kazanabilmenin aracı olduğu düşüncesidir. Bu amaçla paylaşım yapan Insatgram kullanıcılarının paylaşımları bu kez belirli bir hashtag yazılmadan lüks mekânlar üzerinden arama yapılarak seçilmiştir. Aramalar sonucunda genelde aynı tarzda yayınlanan fotoğraflar olduğu görülmüştür. Nitekim Resim 1 ve 4 'te paylaşımların neredeyse birebir örtüştüğü görülmektedir. İstanbul'un en gözde, en 
lüks alış veriş merkezlerinden birinde bir mekânın masasında aynı oturma şekli, aynı el hareketi, aynı lüks marka çantanın ambleminin ifşa edildiği fotoğraf ile variyetlerini sanal kamusal alanda paylaşarak toplumsal bir statü kazanma gayreti içerisinde olan kişiliklerin çok fazla olduğu görülmektedir. Resim 2'de yine aynı alış veriş merkezinde lüks bir mağazanın görüntüsünü arak plana alarak bedeni ve variyetini deşifre etmek suretiyle mahremiyetin ihlal edildiği görülmektedir. Resim 3 de yine lüks bir restoranda yedi yemeği, kendini ve mekânın mahremiyetinin ihlal edildiği bir paylaşım olduğu göze çarpmaktadır. Aynı zamanda kolda takılı olan lüks marka saat ve gözlük ile de varlığın deşifresi söz konusudur.

Mekânlarda çekilen fotoğrafların sosyal medya ortamlarında paylaşılmasının bir diğer sıkıntı yaratabilecek durumu ise kişilerin o anda evlerinde, işlerinde olmadığının deşifre edilmesiyle güvenlik zafiyeti yaratabilme durumudur. Bu durum da gözetlenme arzusuyla paylaşım yapan kullanıcıların göz ardı ettiği önemli bir husustur.

\section{İş Yeri Gizliliğinin İhlali}
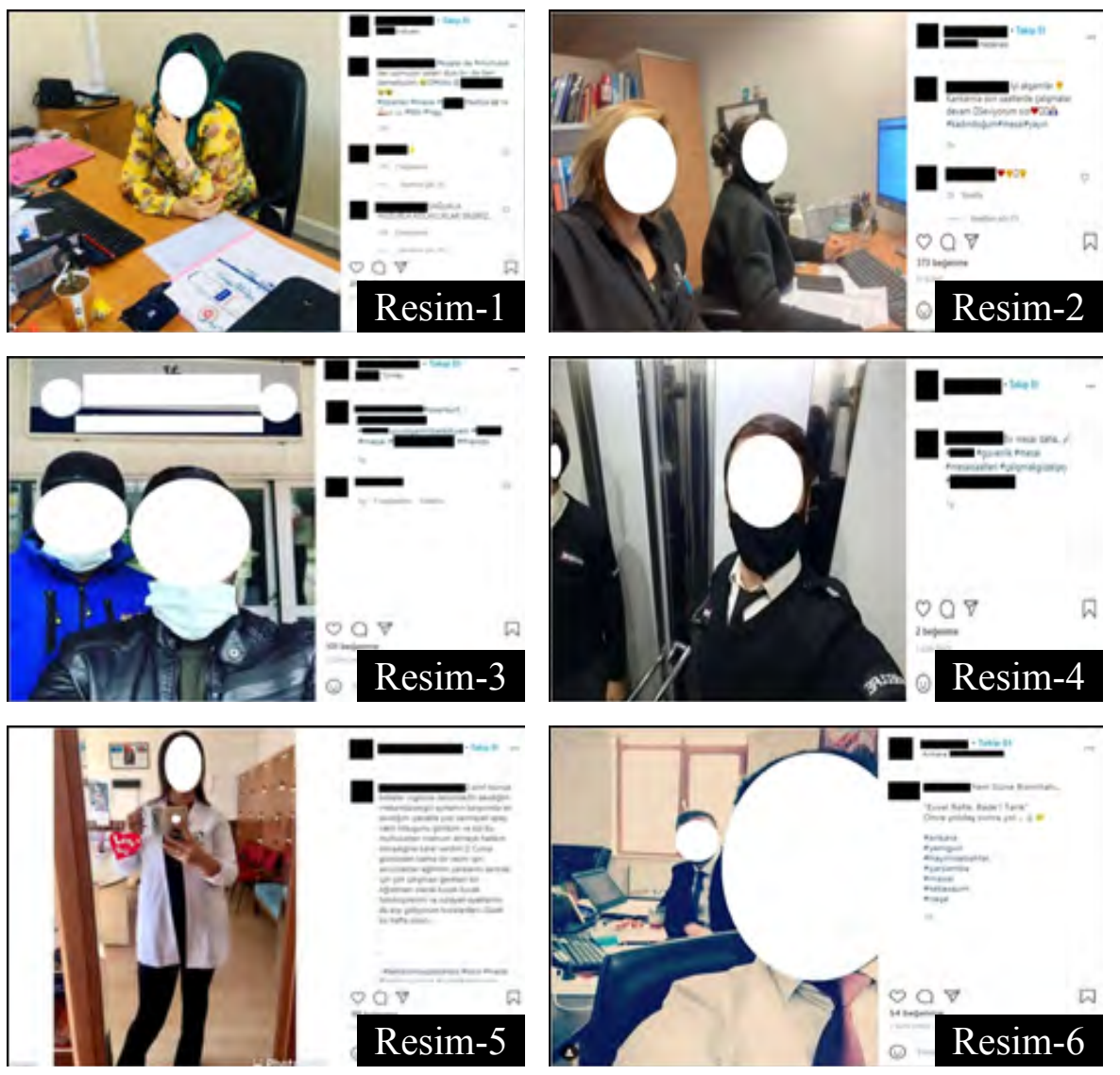

İş yerindeki mahremiyet ve gizlilik çalışanlar tarafından üzerinde özenle hassasiyet gösterilmesi gereken bir durumdur. Ancak bu hassasiyet gösterilmediği gibi bir de gerçek kamusal alanlar sanal kamusal alanlarda bizzat kurumun kendi çalışanları tarafından ifşa edilmektedir. Instagramda \#mesai hashtagiyle yapılan arama sonucunda listelenen 169.051 paylaşım arasından tesadüfi örneklem yöntemiyle seçilen 6 paylaşım analiz edilmiştir. 
Resim 1, 2 ve 6 iş yeri mahremiyeti ve gizliliği bakımından risk taşıyan paylaşımlardır. Çünkü her 3 fotoğrafta da çalışılan masadaki evrakların görülebileceği, bilgisayar ekranlarının da görünmesinden kaynaklı olarak bilgi gizliliğinin açığa çıkarılması bakımından risk taşıyabilmektedir. Resim 5 de bir öğretmen tarafından çoğu zaman o okulun öğrencilerinin bile girilmesine izin verilmeyecek derecede mahrem alan olan öğretmenler odasının sanal ortamda herkesin görebileceği şekilde paylaşılması etik olmayan bir durumdur.

Resim 4'te güvenliği sağlamakla yükümlü olan bir güvenlik personelinin yüzünü ifşa eden fotoğrafi ile güvenliği ihlal edebilecek bir paylaşım sunulmuştur. Bu paylaşım ile kullanıcılar tarafından o güvenlik personelinin o an görevde olmadığı bilinmektedir. Resim 3 'te ise bir belediyenin biriminin adının net bir şekilde arka planda görüldüğü bir mahremiyet ihlali görülmektedir.

\section{Sonuç}

Toplumsal bir varlık olarak yaşamını sürdüren birey iletişim teknolojilerindeki gelişmeler ve yaşanan dönüşüm ile birlikte sosyal medya ortamlarında sosyalleştiğini(!) düşünürken aslında ne kadar yalnızlaştığının farkında bile değildir. Üstelik bu tarz bir sosyalleşme arzusu içerisinde olan birey kendi rızasıyla bedenini, çocuğunu, ailesini, işini, maddi varlığını vb. her türlü mahrem alanını hiç çekinmeden sosyal medya ortamlarında paylaşmaktadır.

Mahremiyetin ihlalinin en can sıkıcı olan alanı, bebeklerin, çocukların masumiyetinin yıkılarak sosyal medya ortamlarında adeta yetişkin bir birey gibi teşhir edilmesidir. Çünkü çocuklar dünyanın en masum yanıdır ve kendilerine ait her türlü mahrem alan sosyal medya ortamlarında paylaşılarak mahremiyet ihlalinin en kirli yüzüyle çok küçük yaşta tanıştırılmaktadırlar. Üstelik bu paylaşımlar çocukların rızası dışında olduğu için ileri yaşlarda kendisinin bu duruma nasıl bir tepki vereceği hiç düşünülmeden. Kullanıcılar, çocuğunu, yeğenini, kuzenini vb. çok şık giydirip sosyal medyada beğeni toplaması adına onlarca fotoğraf çekiyor ve israrla bu fotoğrafta mutlu bir poz vermesi için çabaliyor hatta çocuk sıkıldığını dile getirse bile ısrarcı ve sert bir tavırla o pozu yakalamak için çabalıyorlar. Eski dönemlerde fotoğraf albümlerinde yerini alıp büyüdüğü zaman o dönemlerini görebilsin diye yapılan çekimler şimdilerde hatıra olması amacıyla değil sadece dijital kamusal alanlarda beğeni alması için yapılıyor.

En önemli mahrem alan olan evlerde aile bağlarının en kuvvetlendiği zamanlar olan birlikte aynı masanın etrafında buluşup yemek yeme ritüeli bile illa ki öncesinde bir fotoğraf çekimiyle başlamaktadır. Bazen çok aç olan bebek, bazen ilacını almak için karnını doyurma telaşıyla masaya oturan büyüklerimiz bile fotoğraf çekebilmek için bekletilmektedir. Üstelik bu an çoğu durumda dakikalarca sürmektedir. Öncelikle selfie yapmak için bir gönüllü aranır çünkü en önde olmak çirkin çıkılacağ 1 düşüncesiyle "kendini feda etmek" olarak tabir edilir. Daha sonra feda edilecek(!) olan gönüllü bulunur fotoğraf çekilir hem de defalarca ancak sonrasında neredeyse masada bulunan herkes tarafından o fotoğraflara bakılır herkes öncelikle kendisinin güzel çıkıp çıkmadığını 
inceler. Bir kişi bile durumdan memnun değilse o fotoğraf tekrar tekrar çekilir. Bu arada masadaki yiyeceklere asla dokunulması istenmez ki masa düzeni bozulmadan fotoğraf çekilsin böylelikle özellikle sofrada emeği olan kişi(ler) narsist kişilik bağlamında kendini tatmin edip sosyal medya ortamlarında alacağ duygusunu daha da kabartacaktır. Ve nihayet fotoğraf karesinde olan herkes bir fotoğrafın güzel çıktığı konusunda görüş birliğine varmışsa yemeğe başlama zamanı gelmiştir.

Saatlerce uğraşılan ve emeklerle kurulan sofrada yemek eşliğinde sohbet edip aile birlikteliğini perçinleneceğini düşünüyorsanız işte o noktada yanılıyorsunuz. Çünkü daha sonra o fotoğrafı sosyal medya ortamlarında uygun formatlarda paylaşmak için bir girişim başlıyor. O sırada yemek yeniyor ancak birçok aile bireyi sosyal medya hesaplarında paylaşım yapmak için bir taraftan yemek yemeye çalışırken diğer taraftan da telefonla meşgul oluyor, bu arada asla sohbet edilmiyor. Fotoğraf paylaşılınca da maalesef görev tamamlanmış olmuyor hatta işin en merakla beklenen anına sıra geliyor; fotoğrafı kimler beğendi, kimler yorum yaptı saniye saniye takip ediliyor geri plandan gelen "kızım, oğlum, anne, dayı, teyze hatta bazen anneanne, dede vb. birakır misın o telefonu elinden!" seslenişleri eşliğinde. Sohbet etme zamanı geliyor ancak çoğunlukla sohbet de o zaman yapılan o fotoğraf paylaşımına takipçilerden gelen geri beslemeler üzerine gerçekleşiyor. Sonra bir anda bakıyorsunuz ki "yemek yenmiş, karınlar doymuş" ancak aile birlikteliğe uygun bağları güçlendirmek adına düzenlenen yemek masasından hiç sohbet edilmeden kalkılmış olunuyor. Fotoğraf paylaşımını gören kişilerin belki de "ne kadar güzel bir aile birlikteliği" diyerek gıpta ile baktığı an aslında sadece o pixel içerisinde sıkışan bir aile yemeği. Ama olsun aile birlikteliğinden daha önemli(!) bir anı biriktirdiniz; o da belki gerçek kamusal alanlarda gördüğünüzde çoğu zaman selam vermemek için görmezden geldiğiniz kadar yalnızlaştığınız ama sosyal medya ortamlarında karşılıklı beğenilerde bulunduğunuz insanların beğenisi ve yorumunu aldınız.

Doğum anının mahremiyeti, çalıştığ kurumun mahremiyetini, evlilik kurumunun mahremiyetini, hatta toplumda bir statü ve saygınlık kazanmak adına maddi varlığını bile cehalet içerisinde başkalarının beğenisine sunma hevesinde olan birey bir de benlik duygusuyla "canım kendim" gibi narsist kişiliğin yansıması olan hashtaglerle gözetlenmek ve beğenilmek istemektedir. $\mathrm{Bu}$ da sosyal medya ortamının yaratmış olduğu fantezi dünyada narsist kişiliğe sahip bireylerin giderek arttığını göstermektedir ki kategorisel olarak incelenen paylaşımlarda da bu çok açık bir şekilde görülmüştür. Ayrıca çalışmanın kapsamında örnek olarak seçilen kullanıcıların Instagram hesaplarının herkese açık olması bireysel mahremiyete ters bir durum olmakla birlikte paylaşımlarında yer alan diğer kişilerin de mahremiyet alanlarını ihlal etmesi bakımdan da etik görülmemektedir.

Kısaca özetlemek gerekirse, günümüz modern bireyleri olarak bizler, kitle iletişim araçları, iletişim teknolojileri özellikle de dijital medya sebebiyle hakikatten ve gerçek bilgiden uzaklaştırılarak büyük bir cehaletin içerisine doğru sürüklenmekteyiz (Anık, 2020: 172). Sosyal medya ortamlarında her türlü mahremiyet alanımızı deşifre ederek çağdaş insan olduğumuzu düşünürken aslında tam da bu noktada cehalet çıkmazına girmiş oluyoruz. Üstelik bunu kendi rızamızla kendi irademizle büyük bir hevesle yapıyoruz. Huxley'in “sevdiğimiz şeyler bizi yıkıma götürecek” ütopyasını elbirliğiyle gerçeğe dönüştürdüğümüz bir dünyada manevi değerlerimizi, mahremiyetimizi yıkmak için dörtnala koşuyoruz. 


\section{Kaynaklar}

Anayasa Mahkemesi (2021), https://www.anayasa.gov.tr/media/3542/aihs_tr.pdf Erişim Tarihi: 09.03.2021

Anık, C. (2020). İletişim Bilimine Dair Paradigmaların İşlemezliği. (Ed. Prof. Dr. Cengiz Anık). Dijital Medyanın Ekonomi Politiği. Ankara: Nobel Yayıncılık (s. 117-163).

Anık, C. (2020). Cehaletin Yeniden Üretilmesi ve Takdis Edilmesi. (Ed. Prof. Dr. Cengiz Anık). Dijital Medyanın Ekonomi Politiği. Ankara: Nobel Yayıncılık (s. 165-173).

Arık, E. (2018). Dijital Mahremiyet/Yeni Medya ve Gözetim Toplumu. Konya: Literatürk Acedemia.

Arslan, E. T. ve Demir, H. (2017). Sağlık Çalışanlarının Hasta Mahremiyetine İlişkin Tutumu: Nitel Bir Araştırma. Bolu Abant İzzet Baysal Üniversitesi Sosyal Bilimler Enstitüsü Dergisi, Cilt:17, Sayı: 4 (s. 191-220).

Aydemir, A. (2020). Toplumsal Hareketler ve Sosyal Medya. İstanbul: Kriter Yayınevi.

Baudrillard, J. (2017). Tüketim Toplumu/Söylenceleri, Yapıları (Çev. Nilgün Tutal, Ferda Keskin). İstanbul: Ayrıntı Yayınları.

Belsey, A. ve Chadwick R. (1998). Medya ve Gazetecilikte Etik Sorunlar. (Çev. Nurçay Türkoğlu). İstanbul: Ayrıntı Yayınları.

Bilir, F. (2021). Kişisel Verilerin Korunması Kişinin Kendisinin Korunmasıdır. (Röp. Sezen Yüce). TRT Akademi Dergisi, Cilt 06, Sayı:11, s. 172-181.

Corbetta, P. (2003). Social Research, Theory, Methods and Techiques. London: SAGE Publications Ltd.

Çekiç, S. (2020). İslam Hukukunda Mahremiyet ve Sosyal Medya. Ankara: Türkiye Diyanet Vakfı Yayınları.

Çelikoğlu, N. (2008). Mahremiyet Kişiye Ait Özel Alanlar Tartışması. İstanbul: İskenderiye Yayınları.

Çevik, S. B. (2019). Sosyal Medyada Kuşak Farkı: Facebook Kullanıcılarının Mahremiyet Algısı Üzerine Bir Araştırma, İstanbul Ticaret Üniversitesi, SBE. Yüksek Lisans Tezi.

Duman, B. (2012). Adiye Basın Sözcülüğü. Türkiye Barolar Birliği Dergisi, (101), 293-316.

Erkonan, Ş. (2014). Aile Fotoğrafları: Aile Belleğinin Kurgulamasında Fotoğrafin Rolünü Etnografik Yöntemle İncelemek. Moment Dergi Cilt:1 Say1:2, s.122-147.

Ertürk, Y. D. (2010). Davranış Bilimleri. İstanbul: Kutup Yı1dızı Yayınları.

Fischer-Hübner, S. (1998). Privacy and Security at Risk in the Global Information Society. Information Communication \& Society, 1(4) (p. 420-441). 
Giddens, A. (1992). Mahremiyetin Dönüşümü. Modern Toplumlarda Cinsellik, Aşk ve Erotizm. (Çev. İdris Şahin). İstanbul: Ayrıntı Yayınları.

Gürbilek, N. (2001). Vitrinde Yaşamak, 1980'lerin Kültürel İklimi. İstanbul: Metis Yayınları.

JUDGMENT OF THE COURT (Grand Chamber) (2014), https://curia.europa.eu/ juris/liste.jsf?num=c-131/12 Erişim Tarihi: 17.03.2021.

İspir, N. (2018). Mahremiyetin İhlalinden Değil Aksine Gönüllü Bir İfşadan Söz Edilebilir. TRT Akademi Dergisi. Cilt:03, Sayı:06.

Lokke, E. (2020). Mahremiyet “Dijital Toplumda Özel Hayat” (Çev. Dilek Başak). İstanbul: Koç Üniversitesi Yayınları.

Nacakc1, B. (2018). Sosyal Medyanın İnşaa Ettiği Narsist Kişilikler: Instagram Hesapları Üzerine Bir Analiz (Pilot Çalışma). Uluslararası Sosyal Bilimler Dergisi, Cilt:1, Say1:2 (255-268).

Nalbantoğlu, S. (2018). Bir Temel Hak Olarak Unutulma Hakkı. Türkiye Adalet Akademisi Dergisi, Y11:9 Sayı:35 s. 583-605.

Özdemir, H. (2020). Dijital Mahremiyet. (Muhteva Ed. Ümit Yüksel). İstanbul: İnsan ve Hayat Kitaplı̆̆ 1 .

Özdemir, M. (2010). Nitel Veri Analizi: Sosyal Bilimlerde Yöntembilim Sorunsalı Üzerine Bir Çalışma. Eskişehir Osmangazi Üniversitesi Sosyal Bilimler Dergisi, Cilt 11, Sayı:1.

Solove, D. (2008). Understanding Privacy. Harvard University Press.

Soncu, A. G. (2020). Masumiyetin Linç Edilmesi. (Ed. Prof. Dr. Cengiz Anık). Dijital Medyanın Ekonomi Politiği. Ankara: Nobel Yayıncılık (s. 307-316).

Tumay, S. (2018). Popüler Kültür Bağlamında Düğün Fotoğrafları ve Kıtsch. Dokuz Eylül Üniversitesi Edebiyat Fakültesi Dergisi, Cilt:5 Say1:1 (s.1-17).

Türk Dil Kurumu (2021), https://www.tdk.gov.tr- sozluk.gov.tr/ Erişim Tarihi: 01.03 .2021

Türkmen, B. (2012). Toplumsal Proje ve Kadınlık Deneyimi: İslamcı Kadın Tarafından Yeniden Tanımlanan Mahrem. Cinsiyetli Olmak, Sosyal Bilimlere Feminist Bakışlar. (Derleyen: Zeynep Direk), İstanbul: Yapı Kredi Yayınları.

Yüksel, M. (2003). Mahremiyet Hakkı ve Sosyo-Tarihsel Gelişimi. Ankara Üniversitesi SBF. Dergisi 58(1), 181-213.

Destekleyen Kurum/Kuruluşlar: Herhangi bir kurum/kuruluştan destek alınmamıştır.

Çıkar Çatışması: Herhangi bir çıkar çatışması bulunmamaktadır. 